www.volsu.ru

DOI: https://doi.org/10.15688/nav.jvolsu.2021.1.11

UDC 903' $1(47+57): 726.823$

(c)

LBC 63.442(2)-427

Submitted: 07.03.2021

Accepted: 27.05.2021

\title{
A THIRD CENTURY AD BURIAL VAULT WITH MULTIPLE BURIALS AT THE CEMETERY OF OPUSHKI ${ }^{1}$
}

\author{
Igor N. Khrapunov \\ V.I. Vernadsky Crimean Federal University, Simferopol, Russian Federation
}

\begin{abstract}
Anastasiya A. Stoyanova
Institute of Archaeology of the Crimea of the Russian Academy of Sciences, Simferopol, Russian Federation
\end{abstract}

\begin{abstract}
The cemetery of Opushki is located at $15 \mathrm{~km}$ to the east of modern Simferopol, in the central area of the Crimean foothills. The site has been being excavated since 2003. So far more than 300 graves of various types have been uncovered. They belong to the Late Scythian, Middle Sarmatian, and Late Sarmatian archaeological cultures. There is one cremation complex appeared as a result of the Germanic migration to the Crimea. The complex under present publication belongs to a large group of burial vaults with a short dromos (entry corridor) of the Late Roman period; this type of crypts is found in various cemeteries of the Crimean foothills. Burial constructions of this type are associated with the mediaeval Alans' ancestors who migrated to the Crimea from the North Caucasus. Although the earliest crypts featuring dromos appeared in the foothill area of the Crimean Peninsula in the first half of the $3^{\text {rd }}$ century $\mathrm{AD}$, most of burials in these constructions were made in the fourth century AD. Burial vault no. 158 has two interesting features. It contains multiple burials typical for the Late Scythian vaults of the $1^{\text {st }}$ and the first half of the $2^{\text {nd }}$ centuries. Such a phenomenon is encountered for the first time in the Late Roman vault. According to the analysis of the grave goods, the complex under study is one of the earliest or even the earliest short-dromos vault discovered in the Crimea. It was constructed in the second half (or at the end) of $2^{\text {nd }}$ or very early $3^{\text {rd }}$ century $\mathrm{AD}$ and was in use throughout the first half of the $3^{\text {rd }}$ century. The results of research of this burial construction supply new materials for the solution of highly disputable problem of the Crimean vaults with short dromos origin and of the reconstruction of ethnic processes in the Crimea in the Late Roman period.

Key words: Crimea, Roman period, Opushki cemetery, burial vault, funeral rite, grave goods, ethnic processes.

Citation. Khrapunov I.N., Stoyanova A.A., 2021. Sklep s mnogokratnymi pogrebeniyami III v. n. e. iz mogil'nika Opushki [A Third Century AD Burial Vault with Multiple Burials at the Cemetery of Opushki]. Nizhnevolzhskiy Arkheologicheskiy Vestnik [The Lower Volga Archaeological Bulletin], vol. 20, no. 1, pp. 217-250. DOI: https:// doi.org/10.15688/nav.jvolsu.2021.1.11
\end{abstract}

УДК 903'1(47+57):726.823

Дата поступления статьи: 07.03.2021

ББК $63.442(2)-427$

Дата принятия статьи: 27.05.2021

\section{СКЛЕП С МНОГОКРАТНЫМИ ПОГРЕБЕНИЯМИ ІІІ В. Н.Э. ИЗ МОГИЛЬНИКА ОПУШКИ ${ }^{1}$}

\author{
Игорь Николаевич Храпунов \\ Крымский федеральный университет им. В.И. Вернадского, г. Симферополь, Российская Федерация
}

\section{Анастасия Анзоровна Стоянова}

Институт археологии Крыма РАН, г. Симферополь, Российская Федерация

Аннотация. Могильник Опушки расположен приблизительно в 15 км к востоку от Симферополя, в центральной части крымских предгорий. Раскопки памятника ведутся с 2003 года. К настоящему времени открыто более 300 разнообразных погребальных сооружений. Они относятся к позднескифской, среднесарматской и позднесарматской культурам. Один комплекс представлен кремацией, появление которой обус- 
ловлено продвижением в Крым германцев. Публикуемый комплекс принадлежит большой группе склепов с коротким дромосом позднеримского времени, присутствующих в разных могильниках предгорного Крыма. Такие погребальные сооружения отождествляются с мигрировавшими на полуостров с Северного Кавказа предками средневековых алан. Самые ранние склепы с дромосами появляются в предгорьях полуострова в первой половине III в. н.э., но большинство захоронений в них совершаются в IV в. н.э. Склеп № 158 интересен двумя особенностями. Здесь зафиксирован обряд многократных погребений, типичный для позднескифских склепов I в. до н.э. - первой половины II в. н.э. В склепах позднеримского времени такое явление встречено впервые. Анализ погребального инвентаря свидетельствует, что публикуемый комплекс является одним из самых ранних, если не самым ранним, из раскопанных в Крыму склепов с короткими дромосами. Он был сооружен во второй половине / конце II в. или в самом начале III в. н.э. и использовался в течение первой половины ІІІ в. Результаты исследования этого погребального сооружения дают новые материалы, необходимые для решения дискуссионного вопроса о происхождении крымских склепов с короткими дромосами и реконструкции этнических процессов, происходивших в Крыму в позднеримский период.

Ключевые слова: Крым, римский период, могильник Опушки, склеп, погребальный обряд, погребальный инвентарь, этнические процессы.

Цитирование. Храпунов И. Н., Стоянова А. А., 2021. Склеп с многократными погребениями III в. н.э. из могильника Опушки // Нижневолжский археологический вестник. Т. 20, № 1. С. 217-250. DOI: https://doi.org/ 10.15688/nav.jvolsu.2021.1.11

Могильник Опушки расположен приблизительно в 15 км к востоку от Симферополя, в центре крымских предгорий. Он с перерывами исследуется с 2003 года. За это время раскопано 318 погребальных сооружений различных типов. Открыты два явно отличающихся друг от друга участка. Один, северный, занят позднескифскими погребальными сооружениями I - первой половины II в. н.э., другой - склепами и подбойными могилами III-IV вв. н.э. В позднескифских склепах вход в погребальную камеру выкапывался непосредственно в короткой стене входной ямы. Камера предназначалась для многократных погребений (иногда более 100), совершенных в несколько ярусов. Входную яму после совершения последнего захоронения обязательно заполняли камнями. Склепы позднего участка иные. Входная яма соединялась с погребальной камерой коротким, длиной 0,3-0,8 м дромосом. В ней в один ярус хоронили, как правило, 4-6 человек. Входная яма камнями не заполнялась.

Ситуация, когда оба типа погребальных сооружений присутствуют на одном могильнике, зафиксирована только в Опушкинском некрополе. В других многочисленных могильниках предгорного Крыма открыты либо позднескифские склепы, либо отличающиеся от них склепы позднеримского времени. Склеп № 158 единственный из раскопанных, где сочетаются элементы позднескифских погребальных обрядов и погребальных обрядов позднеримского времени.
Другая причина опубликовать результаты раскопок склепа заключается в дискуссии о происхождении крымских склепов с короткими дромосами. Высказана гипотеза о миграции в Крым с Северного Кавказа предков средневековых кавказских алан, которые принесли с собой обсуждаемые погребальные сооружения. Она убедила не всех исследователей [Храпунов, 2018а]. Для решения проблемы нужны новые материалы и в первую очередь изучение наиболее ранних склепов нового для Крыма типа. Склеп № 158 из могильника Опушки является одним из самых ранних, если не самым ранним, из раскопанных в Крыму склепов позднеримского времени с короткими дромосами, соединяющими входные ямы и погребальные камеры.

Описание погребального сооружения (рис. 1). Прямоугольная в плане входная яма ориентирована с северо-запада на юговосток. Ее размеры $-2,5 \times 0,8$ м, глубина в материке - 1,6 м, от современной дневной поверхности - 2,3 метра. Пол входной ямы относительно ровный. В ее заполнении найден железный нож (рис. 11, $)$ ).

В северной стене входной ямы сделан овальный в плане подбой. Его ширина составляла 0,8 м, длина - не менее 1,7 метра. О длине точно судить нельзя, так как западная часть подбоя, так же как и прилегавший к ней участок входной ямы, уничтожены грабителями. Пол подбоя покрыт угольной подсып- 
кой. На ступеньке между подбоем и входной ямой был установлен заклад из плит. От него сохранилась восточная часть, западная разрушена грабителями. Перемещенные грабителями плиты находились в заполнении их шурфа, разрушившего западные части подбоя и входной ямы.

Вход в дромос сделан в восточной стене входной ямы. Он арочной формы, шириной 0,95 м, высотой 0,8 метра. Вход был закрыт многочисленными плитами. Из них in situ coхранились только две. Остальные сползли и, располагаясь под различными углами, заполнили прилегающую ко входу часть входной ямы, а также дромос, частично разрушив его южную стенку. В уничтожении южной части дромоса приняли участие и грабители. В результате размеры дромоса можно установить только в направлении с запада на восток, между входной ямой и погребальной камерой. Это расстояние составило 0,4 метра.

Погребальная камера прямоугольная в плане, размером 2,4 × 2,2 метра. Стенки сохранились в высоту на 0,2-0,3 м, выше они осыпались. Длинная ось погребальной камеры перпендикулярна длинной оси входной ямы.

Погребальная камера была заполнена рухнувшим сводом. Грабители перекопали ее южную часть, приблизительно половину. В месте разграбления заполнение состоит из суглинка рухнувшего свода и включений темной земли. В перекопанном грабителями заполнении найдены два бронзовых браслета (рис. 10,1,2), железная пряжка (рис. 10,8), пять обломков железных ножей (рис. 10,3-7), фрагмент пряслица (рис. 10,9), бусы (рис. 10,10-26), обломки лепного сосуда (рис. 11,1,2).

Пол погребальной камеры расположен на 0,5 м ниже пола дромоса. Переход оформлен в виде ступеньки. Пол погребальной камеры был полностью покрыт угольной подсыпкой.

В камере обнаружены останки не менее 19 погребенных: 11 детей 2-14 лет, 3 мужчины, 4 женщины, пол одного погребенного не установлен ${ }^{2}$.

В южной, разграбленной части погребальной камеры на полу сохранились некоторые человеческие кости, в том числе череп. Они условно названы погребением I (рис. $2, A$, $3, A)$. Несколько костей вместе с несколькими бусинами лежали под плитой размером
$0,4 \times 0,3$ метра. Кроме человеческих костей, обнаружены кости животных, а также краснолаковая миска (рис. 6,6), многочисленные бусы (рис. 9,1-19,25-27), железный нож (рис. 6,1), дисковидный бронзовый предмет (рис. 5,13), украшенный стеклянной вставкой (рис. 5,11 ), и янтарная подвеска (рис. 5,12 ).

От детского погребения II, которое с юга примыкало к многочисленным костям, занимавшим северную часть склепа, после разграбления сохранились кости ног (рис. 2,Б). Судя по их положению, погребение было совершено в вытянутом положении на спине головой на запад. Рядом с остатками погребения II, к западу расчищено пятно органического тлена коричневого цвета размером $0,28 \times 0,18$ метра. На нем лежали бронзовые фибула (рис. 5,2 ), гривна (рис. 7,8 ) и несколько бусин (рис. 9,20-24). Между бедренными костями погребения II найдены обломки бронзового (рассыпался) и железного (рис. 7,1) браслетов. На левой бедренной кости лежали два бронзовых браслета (рис. 7,2,3), слева от нее - стержневидный железный предмет с деревянной рукояткой (рис. 5,15).

Северная часть погребальной камеры у стенки была занята костями погребенных, располагавшихся в 4 яруса (рис. 2, $5,3, A$ ). Большинство костей сдвинуто при подзахоронениях, но некоторые остались в первоначальном положении. Лучше других сохранились погребения III и IV, занимавшие верхний ярус. Оба совершены в вытянутом положении на спине, головами на запад. Левая кисть погребенного III лежала на тазовых костях.

На черепе погребенного III расчищены кость животного и лепной сосуд (рис. 6,7). На месте груди лежали фибула (рис. 5,4), бусина (рис. 9,29 ) и бронзовая пронизь (рис. 9,28 ). На левую руку был надет бронзовый браслет (рис. 7,7). На левой бедренной кости лежала бронзовая пряжка (рис. 5,10), между берцовыми костями - железная пряжка (рис. 5,5), бронзовое кольцо (рис. 5,7), кремень (рис. 7,9) и астрагал (рис. 5,14). Найденная под правым плечом погребенного краснолаковая тарелка (рис. 6,3), располагавшийся рядом с черепом краснолаковый кувшин (рис. 6,5), краснолаковая тарелка (рис. 6,4) с ножом (рис. 6,2) под левым плечом, по всей вероятности, относились к погребенным второго яруса. То же 
можно сказать о найденной слева от бедренных костей монете (рис. 7,10).

Между погребенными III и IV располагалась бронзовая фибула (рис. 5,1).

В головах погребенного IV лежала обугленная деревянная плашка. На месте его шеи (рис. 9,30-36) и груди (рис. 8,1-5) обнаружены бусы, на тазовых костях - бронзовый браслет с надетым на него перстнем (рис. 5,8,9), на месте левого колена - пряслице (рис. 7,12). На берцовых костях погребенного расчищено 15 рядов бус, вероятно, расшивавших подол платья (рис. 4, $B, 8,17-39$ ).

Во втором ярусе, судя по количеству черепов, совершили 10 погребений (V-XIV). Подавляющее большинство костей перемещено при подзахоронениях (рис. 3,Б). Удовлетворительно сохранилось погребение V у самой стенки погребальной камеры, но и оно лишено черепа. Погребение V совершено в вытянутом положении на спине головой на запад. На месте груди сохранились бронзовая пронизь (рис. 8,11) и бусы (рис. 8,12,13). На месте сохранились кости еще от четырех ног погребенных. Их положение также указывает на западную ориентацию захоронений. Из-за перемещения костей невозможно соотнести с тем или иным погребением погребальный инвентарь. Во втором ярусе погребений обнаружены многочисленные бусы (рис. 8,610), бронзовые кольцо (рис. 5,3) и два браслета (рис. 7,5,11), один из которых расчищен надетым на лучевые кости, оселок (рис. 5,16).

В третьем ярусе сохранились кости трех погребенных (XV-XVII). На месте зафиксированы расположенные рядом со стенкой погребальной камеры кости ног и таза погребения XVII. Судя по их положению, погребенный был положен в вытянутом положении на спине головой на запад (рис. 4,A). Под его берцовыми костями лежал обломок краснолаковой тарелки (рис. 6,8). Отдельные сохранившиеся in situ кости других погребенных также указывают на их положение на спине головами на запад. Среди костей обнаружены бусы, которые, возможно, провалились из второго яруса погребений.

В четвертом ярусе, расположенном на полу погребальной камеры, расчищены останки двух подростков (рис. 4,Б). От погребения XIX сохранились только некоторые кости таза и ног, от погребения XVIII - большая часть костяка, исключая кости ног ниже колен, кисти, часть ребер и др. Оба погребения были совершены в вытянутом положении на спине, головами на запад. Кости ног погребенного XVIII широко расставлены (возможно, смещены при подзахоронениях, но именно ноги, а не кости, до того, как мягкие ткани успели разложиться), у головы лежал плоский камень. На нем найдены пряслице (рис. 7,4) и бронзовая пронизь (рис. 7,6). Бусы обнаружены на месте груди (рис. 8,14-16). Под левой бедренной костью лежал обломок краснолаковой миски, той самой, фрагмент которой оказался в третьем ярусе погребений (рис. 6,8). Между бедренными костями найдено бронзовое кольцо на фаланге пальца (рис. 5,6).

В заполнении погребальной камеры найдены пряслице (рис. 11,4), фибула (рис. 11,3) и бусина (рис. 11,5).

Погребальный инвентарь. Монета (рис. 7,10$)^{3}$. Серебро. Денарий. Септимий Север. 204 г. н.э.

Л.с.: Бюст бородатого императора в лавровом венке вправо. Вокруг надпись: SEVE(RVS)-PIV(S AVG). Точечный ободок.

O.c.: Гений в рост, влево, правой рукой совершает возлияние из патеры на алтарь слева, в левой руке колоски. Вокруг надпись: Р. М. TR. P. X [II COS.] IIIP. P. Точечный ободок.

Аналогии: [Mattingly, Sydenham, 1936, p. 117 , no. 195]. Однако возможны еще два варианта: 206 г. н.э. [Mattingly, Sydenham, 1936, p. 117, no. 201], с реконструкций легенды реверса ... P. X. [IIII COS.] ...; 207 г. н.э. [Mattingly, Sydenham, 1936, p. 118, no. 209], с реконструкцией реверса ... Р. X. [XV COS.]... .

Сохранность монеты удовлетворительная. Лицевая и оборотная стороны частично затерты, края неровно обрезаны, с выщерблинами. Соотношение осей: 12:1(?).

Краснолаковые сосуды. Миска с усечено-коническим туловом, загнутым внутрь верхним краем, на кольцевом поддоне. Лак ярко-оранжевого цвета покрывает всю внутреннюю поверхность сосуда и верхнюю часть с внешней стороны (рис. 6,6). Найдена на полу в разграбленной части склепа. Подобные миски встречаются иногда в крымских комплексах первой половины III в. н.э. [Пуздровский, 2007 , с. 195 , рис. 186,12$]$. 
Остальные сосуды найдены в погребениях второго яруса у северной стены погребальной камеры. Две однотипные тарелки с усечено-коническим туловом, вертикальным бортиком, на кольцевом поддоне. Место перехода тулова к бортику оформлено ребром. $\mathrm{У}$ одной из них лак темно-коричневого цвета покрывал всю внутреннюю поверхность сосуда и бортик с внешней стороны (рис. 6,4). У другой лак темно-оранжевого цвета, сохранился местами (рис. 6,3). Обе тарелки относятся к Понтийской сигиллате А, соответствуют форме 4.2 Д.В. Журавлева [Журавлев, 2010 , с. 46,47$]$ и типу III-Д-3 А.А. Труфанова [Труфанов, 1997, с. 189]. С датой вторая половина II - первая половина III в. н.э. согласны оба исследователя.

Кувшин одноручный с расширяющимся в нижней части туловом, раструбообразным горлом с отогнутым верхним краем, на кольцевом поддоне. Ручка крепилась к горлу и плечу тулова. Лак темно-коричневого цвета сохранился местами (рис. 6,5). Кувшин более всего похож на сосуды типа 2 по классификации О.В. Шарова [Шаров, 2007, с. 46-49] и форму 39 по Д.В. Журавлеву [Журавлев, 2010, c. 89,90$]$. Много таких сосудов обнаружено в крымских комплексах ІІІ в. н.э., но в могильнике Дружное они найдены в погребениях IV в. н.э. [Храпунов, 2002, с. 59, 60]. Публикуемый сосуд имеет индивидуальную особенность. Его край отогнут менее резко, чем у всех известных нам экземпляров.

Лепные сосуды представлены двумя одноручными кувшинами с туловом биконической формы. У одного из них слегка отогнутый верхний край (рис. 6,7), у второго верхняя часть отсутствует (рис. 11,1,2). Кувшины подобной формы известны в погребениях предгорного Крыма III-IV вв. н.э. [Власов, 1999 , с. 344 , рис. $12,10,11$; Храпунов, 2002, с. 64 , тип LVIII; 2011a, с. 20, рис. 37,3; Суханов, 2020, с. 70 , рис. 2,22].

Фибульл. В склепе найдены 5 фибул (одна из них - железная - распалась):

1. Фибула бронзовая лучковая подвязная одночленная. Найдена в разграбленной части склепа (рис. 5,2). По классификации А.К. Амброза относится к группе 15 , серии I, варианту 5 с датой конец II - III в. н.э. [Амброз, 1966, c. 51]. По классификации В.В. Кропотова со- ответствует застежкам группы 4, серии I, варианту 4 с датой конец II - первая половина III в. н.э. [Кропотов, 2010, с. 77-80].

2. Фибула бронзовая лучковая подвязная одночленная. Найдена в верхнем ярусе погребенных в северной части погребальной камеры (рис. 5,4). По классификации А.К. Амброза относится к группе 15 , серии I, варианту 4 с датой вторая половина II - возможно, начало III в. н.э. [Амброз, 1966, с. 50, 51]. По классификации В.В. Кропотова соответствует застежкам группы 4, серии I, варианту 4 с датой конец II - первая половина III в. н.э. [Кропотов, 2010, с. 77-80]. В.В. Кропотов не разделяет варианты 4 и 5 А.К. Амброза. Спинка фибулы обмотана проволокой, но этот признак не считается хронологическим.

3. Фибула бронзовая лучковая подвязная одночленная. Найдена в верхнем ярусе погребенных в северной части погребальной камеры (рис. 5,1). Отличается от фибул 1 и 2 нижней тетивой. По классификации А.К. Амброза относится к группе 15 , серии II («инкерманской»), варианту 1 с датой вторая половина II - III в. н.э. [Амброз, 1966, с. 52]. По классификации В.В. Кропотова соответствует застежкам группы 4, серии II, варианту 4, форме 1 с датой конец II - первая половина III в. н.э. [Кропотов, 2010, с. 132-136].

4. Фибула бронзовая лучковая подвязная одночленная с фигурной обмоткой спинки. Найдена в заполнении погребальной камеры (рис. 11,3).

Подробный анализ фибул 4 и 5 вариантов А.К. Амброза с обмоткой спинки, сочетающей кольцевую навивку и серпантин, по нижнедонским материалам предприняли С.И. Безуглов и Л.Ю. Нидзельницкая. Их вывод: такие фибулы датируются концом II - ранней частью III в. н.э. [Безуглов, Нидзельницкая, 2020, с. 245-248]. До проведения специального исследования предварительно можно сказать, что этот вывод вполне согласуется с крымскими материалами.

Пряжки представлены тремя экземплярами. Одна из них бронзовая, с железным язычком (рис. 5,10), две - железные (рис. 5,5, $10,8)$. Их типы определить проблематично изза коррозии.

Бронзовая тордированная гривна из круглой в сечении проволоки сопровождала 
погребение II в северной части камеры. Один конец гривны раскован, в нем сделано отверстие, второй конец отсутствует, но, вероятнее всего, он был оформлен в виде крючка (рис. 7,8). Соответствует типу 8Б по классификации А.А. Стояновой [Стоянова, 2011а, c. 121]. В крымских памятниках подобные гривны единичны и связаны с комплексами, сформировавшимися не раннее середины III в. н.э. [Храпунов, 2002, с. 41, 68, рис. 95,10; Мыц и др., 2006, с. 157-158, 161, табл. 18,8, 25,$9 ;$ Гайдукевич, 1959, с. 222-223, рис. 95,1], что позволило отнести эту группу находок к числу немногочисленных для Крыма хроноиндикаторов второй половины III в. н.э. [Стоянова, 2011a, с. 124]. К этому же времени, с возможным заходом в ранний IV в. н.э., относятся редкие находки гривен этого типа в позднесарматских погребениях [Безуглов, Захаров, 1989, с. 56]. Однако новые материалы заставляют расширить эту датировку. Тордированная гривна с аналогичной конструкцией замка сопровождала могилу № 942 Усть-Альминского некрополя. Авторы публикации датировали комплекс второй половиной II - началом III в. н.э. [Пуздровский, Труфанов, 2017 a, с. 85-86, рис. 186]. Но скорее всего погребение было совершено в первой половине III в. н.э., так как именно к этому времени относятся все известные в крымских памятниках находки крупных подвесок-лунниц с припаянной петелькой, подобные обнаруженной в могиле № 942 [Пуздровский, Труфанов, 2017a, рис. 186,4 ; Пуздровский, 2007, с. 152 ; Стоянова, 2016, с. 135-136]. Стеклянный бальзамарий с шаровидным туловом из этого же погребения вряд ли поможет скорректировать дату, но и не противоречит ей: подобные сосуды, но меньших размеров, бытовали в III вв. н.э. [Алексеева, Сорокина, 2007, с. 62], а более крупные колбообразные образцы из могильников предгорного Крыма связаны преимущественно с комплексами III-IV вв. н.э. [Пуздровский, 2007, рис. 191,7-9; Шабанов, 2020 , с. 395$]^{4}$.

В Крыму известны еще две гривны с замком, оформленным так же, как и в экземпляре из публикуемого склепа, но сделаны они из гладкой, круглой в сечении проволоки (тип 8А) [Стоянова, 2011a, с. 121]. Одна - из могилы 176 могильника Перевальное [Пуздровский,
2007, рис. 125,3]. В этом же комплексе присутствовали бронзовая лучковая подвязная фибула варианта 5 по А.К. Амброзу ${ }^{5}$ и две, превращенные в подвески, боспорские монеты с надчеканкой времени Савромата II (174/ 5 -210/11 гг. н.э.) [Труфанов, 2019, с. 576], позволяющие датировать погребение концом II - первой половиной III в. н.э. Вторая гривна найдена в Опушкинском некрополе в могиле № $213^{6}$. В состав инвентаря входила бронзовая пряжка типа П2б по классификации В.Ю. Малашева [Малашев, 2000, с. 195], два наконечника ремней, один из них фасетированный, подобный наконечнику из могильника Нейзац типа X/2 [Храпунов, 2008, с. 68, рис. 6,6], другой - без фасеток, близкий по форме типу Н3а [Малашев, 2000, с. 197]. Набор ременной гарнитуры датирует погребение III в. н.э., а краснолаковая тарелка с вертикальным бортиком формы 4.2 по Д. В. Журавлеву [Журавлев, 2010, с. 46-47] позволяет сузить дату комплекса до первой половины столетия. Следовательно, гривны с замком в виде раскованного конца с отверстием и крючком - и гладкие, и тордированные - появляются в Крыму в первой половине III в. н.э., возможно, ближе к середине столетия. Этот вывод подтверждается тем, что в публикуемом склепе гривна сопровождала погребение II вместе с лучковой фибулой 5-го варианта, а само погребение совершено явно позже многоярусных захоронений у северной стенки камеры. Во второй половине III в. н.э. такие украшения распространяются в сарматской степи за пределами полуострова, а с рубежа III IV вв. н.э. - в рязано-окских могильниках лесостепи [Ахмедов, 2007, с. 142; Белоцерковская, 2007, с. 192 , рис. $3,20,4,3]$. Существенно расширяется их количество и ареал в гуннское время [Khrapunov, Kazanski, 2016, S. 370371, fig. 3,2; Мастыкова и др., 2016, с. 18 19, табл. 14; Ставицкий, 2015].

Браслеты. Всего в склепе обнаружено восемь браслетов, один железный (рис. 7,1$)$ и семь бронзовых (рис. 5,8, 7,2,3,5,7,11, 10,1,2). Все они простейших форм, выполнены из круглой или прямоугольной в сечении проволоки, с незамкнутыми, в некоторых случаях утолщенными концами. Находят многочисленные аналогии в синхронных крымских памятниках. Четыре браслета (целым сохранился лишь 
один) сопровождали погребение II. По всей видимости, они были надеты на руки ребенка, по два на каждую. Один из браслетов украшала стеклянная бусина (рис. 7,2). На тазовых костях погребенной IV лежал браслет с надетым на обод перстнем (рис. 5,8,9). Соединение браслетов с другими предметами крайне редко фиксируется в крымских погребениях. В Усть-Альминском могильнике и некрополе Совхоз-10 на браслеты были надеты колокольчики [Высотская, 1994, табл. 28,60, 45,6; Стржелецкий и др., 2005, табл. 17,43], в одном из погребений могильника Совхоз-10 маленькая фибула [Стржелецкий и др., 2005, табл. 7,21], в детском погребении из Опушкинского могильника - пронизь [Стоянова, 2012 , рис. 28,3$]$, в склепе из некрополя ТасТепе - бусы [Пуздровский и др., 2001, рис. 7,8].

Бронзовый перстень с прямоугольной в сечении шинкой и раскованным овальным щитком, к которой без гнезда прикреплена сердоликовая вставка (рис. 5,9), по форме относится к числу наиболее распространенных в крымских памятниках I-III вв. н.э. [Гавритухин и др., 2020, с. 104, рис. 6,25; Лысенко и др., 2015, с. 311 ; Высотская, 1994, с. 114 115 , рис. $34,12,13$; Храпунов, 2011a, с. 43, рис. $45,11,14,15]$. На плоской лицевой стороне вставки изображен знак в виде шестилучевой звезды. Две подобные интальи присутствуют на перстнях из Усть-Альминского могильника [Пуздровский, Труфанов, 2017a, рис. $37,4,206,13]$. Звезда с шестью или восьмью лучами на геммах часто сочетается с полумесяцем, причем этот сюжет получает распространение в римское время и как самостоятельное изображение [Максимова, 1957 , с. 80 , рис. 3,8 ; Высотская, 1980 , с. 100 , рис. 1,22,23; Краснодубец, 2019, рис. 1], и как часть более сложной композиции [Неверов, 1979, табл. III,25-27; Cravinho, 2017, p. 226, Pl. 6,21; Spier, 1992, p. 124, no. 327, p. 137, no. 373]. Помимо глиптики, знак в виде звезды, стилистически очень близкий изображенному на публикуемой гемме, в качестве дифферента используется в монетной чеканке Боспора: появляясь на монетах Тиберия Юлия Евпатора, он особенно часто присутствует на монетах Савромата II и Рескупорида II [Анохин, 1986, с. 113-119; БертьеДелагард, 1911, с. 4-6].
Бусы. Коллекция бус из склепа насчитывает 985 экземпляров. Они сделаны из одноцветного стекла (54 \%), многоцветного стекла $(0,4 \%)$, стекла с внутренней металлической прокладкой (34\%), гагата (9\%), египетского фаянса $(0,1 \%)$, янтаря $(0,7 \%)$, камня $(1,4 \%)$ и бронзы $(0,4 \%)$. Бусы представлены 42 типами. Среди одноцветных стеклянных бус преобладают красные и белые пронизи цилиндрической формы, составляющие почти $79 \%$ украшений из этого материала. Доминирующим типом бус с позолотой являются бусы округлых форм, а среди гагатовых короткоцилиндрический бисер (табл. 1).

Набор бус из публикуемого комплекса существенно отличается от наборов из позднескифских склепов, где и число этих украшений обычно значительно больше, и состав типов совершенно другой (для сравнения см.: [Храпунов и др., 2009, с. 19-32; Храпунов, Стоянова, 2020, с. 93-103; Мульд, Масякин, 2003, c. 16-20, табл. 1]). Не находит он соответствий и в погребениях IV в. н.э., в которых бусы немногочисленны, а в наборах преобладают мелкие одноцветные округлые бусы из синего и зеленого стекла в сочетании с янтарными украшениями [Хайрединова, 1995, с. 82-83; Стоянова, 2004, с. 303; Храпунов, 2018б, с. 143; Храпунов, 2011б, с. 18-19].

Бусы сопровождали 8 погребенных одно мужское (погр. III), одно женское (погр. IV), пять детских (погр. I, II, VII, XIII, XVIII, возраст от 3 до 12 лет) и одно погребение индивида старше 20 лет (погр. V, пол не установлен). Рассмотрим индивидуальные наборы, зафиксированные в некоторых из этих погребений.

Погребение XVIII (подросток $12-$ 14 лет). Короткоцилиндрические гагатовые пронизи (рис. 8,15 ) в сочетании с двумя цилиндрическими стеклянными бусинами (рис. 8,16 ) и гагатовой подвеской (рис. 8,14) составляли небольшое ожерелье. Набор соответствует наборам группы 1, выделенным при изучении женских погребений Нейзацкого могильника [Стоянова, 2011б, с. 119].

Основу ожерелья, расположенного на груди погребенного V, составляли вытянутые, длиной 2,2-4,5 см, цилиндрические пронизи из стекла с внутренней металлической прокладкой (рис. 8,13). Такого размера бусы зафик- 
сированы впервые. Известные в античных памятниках и могильниках предгорного Крыма немногочисленные пронизи этого типа не превышают в длину 2,5 см [Алексеева, 1978, с. 30 , тип 4; Хайрединова, 1995, с. 72 , тип 86; Стоянова, 2004, с. 286, тип 4].

В детском погребении XIII (рис. 8,9,10) и в мужском погребении III (рис. 9,28,29) по 2 крупных бусины - многоцветная стеклянная и бронзовая - лежали рядом в районе грудной клетки. Наличие крупных единичных бусин в мужских погребениях обычно объясняется использованием их в качестве пуговиц. Расположение бус в нашем случае позволяет подтвердить это мнение и реконструировать способ застегивания верхней распашной одежды с помощью таких предметов. По всей видимости, по одной бусине пришивали к каждому краю куртки и при застегивании обе бусины соединяли с помощью шнурка. Стоит отметить, что кроме пары бус у обоих погребенных чуть ниже на груди присутствуют фибулы, которые могли служить дополнительной застежкой той же куртки или верхней накидки.

Погребение II, принадлежавшее ребенку 3-4 лет, сопровождалось коротким ожерельем, порядок расположения бус в котором зафиксирован при расчистке. Его основу составляли три крупных предмета: в центре располагалась бусина из халцедона (рис. 9,20), по бокам от нее - бронзовая пронизь (рис. 9,22 ) и бусина с пятнистым орнаментом (рис. 9,21). Рядом с бронзовой бусиной лежали две небольшие цилиндрические бусины из белого и красного стекла (рис. 9,23,24). Использование бус больших размеров из полихромного стекла, египетского фаянса или гагата в коротких ожерельях, часто в сочетании с разнообразными подвесками, фиксируется в детских погребениях на протяжении всего римского времени [Хайрединова, 1995, с. 80; Стоянова, 2012, рис. 59, 60; Храпунов, 2006, с. 171].

Наиболее многочисленный по количеству бус набор сопровождал погребение IV, принадлежавшее женщине 30-40 лет. Бусы концентрировались в верхней части костяка и в ногах умершей. На шее расчищено, по всей видимости, два коротких ожерелья. В центре одного из них располагалась подвеска в виде мужских гениталий из фаянса (рис. 9,32), от которой в обе стороны отходили пронизи из стекла с внутренней позолотой (рис. 9,36). Из этих же пронизей, дополненных несколькими гагатовыми (рис. 9,31) и сердоликовыми (рис. 9,35) бусинами, состояло второе ожерелье. Еще одно длинное ожерелье, спускающееся почти до живота умершей, по всей видимости, составляли бусы, расчищенные в район грудной клетки. В него входили гагатовые цилиндрические (рис. $8,1,2)$ и округлые сердоликовые (рис. 8,3 ) пронизи, дополненные несколькими янтарными (рис. 8,5 ) и стеклянными (рис. 8,4). Этот набор можно, так же как и ожерелье в погребении XVIII, отнести к 1-й группе наборов, характерных для женских захоронений Нейзацкого могильника [Стоянова, 2011б, с. 119].

Берцовые кости погребенной практически полностью перекрывали расположенные горизонтальными рядами бусы, среди которых существенно преобладали округлые с металлической прокладкой (рис. 8,30,31) и цилиндрические из красного и белого стекла (рис. $8,17,18$ ). При расчистке погребения удалось зафиксировать не менее 15 рядов длиной около 25 см, плотно прилегающих друг к другу. Некоторые ряды состояли из бус одного типа или цвета (рис. 4,B). Таким же образом бусы располагались под берцовыми костями. Из этого набора сохранилось более 500 экземпляров бус, значительное число бусин рассыпалось при расчистке и снятии костяка. Очевидно, бусами был расшит подол платья. Аналогичные наборы, выделенные в группу 5 [Стоянова, 2011б, с. 120], известны в могильниках Нейзац, Курское, Левадки, Фонтаны, а также в других комплексах Опушкинского некрополя. Во всех случаях они сопровождают женские захоронения, фиксируются на берцовых костях и довольно часто сочетаются в погребении с лучковыми подвязными фибулами 4 и 5 вариантов, а также с фибулами «инкерманской» серии, что позволяет датировать их второй половиной II - первой половиной ІІІ в. н.э. [Храпунов и др., 2001, с. 123128; Стоянова, 2011б, с. 121, 141, табл. 4; Труфанов, 2004 , с. 499 , рис. 2 , с. 507 , рис. 8 , с. 511 , рис. 11]. На этом фоне выделяется набор, найденный в опушкинском склепе № 133: бусы лежали не на костях ног, а рядом с погребенным, в углу гроба; в наборе присутствует около полусотни пронизей и подвесок из гагата; 
рядом с бусами лежала стопка монет, самая поздняя из которых - Траяна Деция выпуска 249-251 гг. - свидетельствует о том, что данное погребение не могло быть совершено раньше середины III в., а сам склеп использовался для захоронений в течение второй половины III - начала IV в. [Храпунов, 2020, c. 253,255$]$. Стоит отметить, что погребения с рассматриваемыми наборами бус совершались в подбойных или, реже, грунтовых могилах. Опушкинский некрополь - пока единственный памятник, где такие случаи зафиксированы в склепах, причем in situ ${ }^{7}$. И наконец, последнее наблюдение, связанное с данным феноменом: за пределами предгорного Крыма такие наборы неизвестны, то есть имеются все основания полагать, что традиция украшения подола платья, нижнего края штанов или голенищ обуви большим числом пронизей определенных типов сложилась именно в крымских предгорьях в середине II в. н.э. и бытовала здесь как минимум сто лет, полностью исчезнув во второй половине III века ${ }^{8}$.

Датировка. Основой для датировки склепа послужили фибулы и монета. В верхнем ярусе погребенных у северной стены погребальной камеры найдены две фибулы второй половины или конца II - первой половины III в. н.э. Ярусом ниже обнаружена монета 204 г. н.э. Ниже располагались еще два яруса погребений без датирующих находок. Следовательно, хоронить в склепе, во всяком случае, в его неразграбленной части, начали во второй половине / конце II или в самом начале III в. н.э. и продолжали в течение первой половины III в. н.э. Такую датировку подтверждают две фибулы, найденные вне стратиграфического контекста.

Время использования двух однотипных краснолаковых тарелок и кувшина, положенных во второй ярус погребенных у северной стены погребальной камеры, а также наборов бус и гривны вполне соответствует датировке по фибулам и монете.

Обращает на себя внимание наличие в склепе всего двух лепных сосудов. Уже давно подмечено, что в погребениях предгорного Крыма III в. н.э. лепные сосуды единичны. В IV в. н.э. их количество многократно возрастает [Храпунов, 2011a, с. 21] ${ }^{9}$.
Склеп № 158 ничем принципиально не отличается от других крымских склепов позднеримского времени. Правда, дромос частично разрушен и прослежен не во всех деталях, но факт его наличия сомнений не вызывает. Вход, сделанный в короткой стене входной ямы, ведет не непосредственно в погребальную камеру, что характерно для позднескифских склепов. Расстояние между входной ямой и погребальной камерой составляет 0,4 метра. Это расстояние соответствует длине дромоса. Обычным для склепов позднеримского времени является наличие подбоя во входной яме. Например, в могильнике Нейзац подбои зафиксированы в 19 из 87 раскопанных склепов [Мульд, 2016, с. 41]. Есть такие погребальные сооружения и в могильнике Опушки [Храпунов, 2018б]. В позднескифских склепах подбои в стенах входных ям неизвестны. Угольные подсыпки, вроде тех, что покрывали полы подбоя в стене входной ямы и в погребальной камере, характерны для погребальных сооружений различных типов позднеримского времени [Храпунов, 2011a, с. 21], в том числе открытых (но еще не опубликованных) в могильнике Опушки.

Многоярусные, без прослоек земли между ярусами, погребения - один из самых характерных признаков позднескифской археологической культуры. Он зафиксирован при раскопках всех позднескифских могильников со склепами (см., например: [Сымонович, 1983, с. 28-58; Высотская, 1994, с. 50-55; Храпунов и др., 2009]). В склепах позднеримского времени такой обряд ранее не был известен, за исключением подобного, но не идентичного, случая в могиле № 306 Нейзацкого некрополя [Храпунов, 2011б, с. 5-7]. Обнаруженный в публикуемом склепе погребальный инвентарь состоит из вещей, обычных для всех типов крымских погребальных сооружений первой половины III в. н.э. Он не отражает этнокультурную дифференциацию могильников или отдельных погребений.

Как случилось, что в одном погребальном сооружении сочетались признаки разных археологических культур? Логичным, хоть и умозрительным, кажется следующий ответ на поставленный вопрос. Во второй половине II или в самом начале III в. н.э. в предгорном Крыму появились носители культуры склепов 
с короткими дромосами. Они столкнулись с людьми, сохранившими позднескифские погребальные традиции. Мигранты и автохтоны создавали единые коллективы. В результате формировались погребальные обряды, сочетавшие разные по происхождению элементы. Вероятно, носителей позднескифских традиций было не много. Поэтому в синхронных и однотипных склепу № 158 погребальных сооружениях хоронили по новым для предгорного Крыма правилам - в один ярус на полу погребальной камеры. У этой гипотезы есть слабое место. Дело в том, что позднескифские склепы перестали использоваться в первой половине или около середины II в. н.э. ${ }^{10}$ Следовательно, между самыми поздними позднескифскими склепами и склепом № 158 из могильника Опушки существует хронологический разрыв, который пока нечем заполнить. Впрочем, если склеп № 158 выкопали во второй половине II в. н.э., что вполне вероятно, хронологический разрыв может оказаться совсем небольшим.

Теоретически возможна и альтернативная гипотеза. Без внешнего влияния жители предгорного Крыма отказались от традиционных для них погребальных сооружений и перешли к строительству склепов с короткими дромосами, кардинально изменив погребальные обряды. Но для доказательства такой гипотезы, кажется, нет ни фактических, ни логических обоснований.

В последние годы опубликованы результаты раскопок, еще более запутывающие ситуацию. В Усть-Альминском позднескифском могильнике, среди множества типичных для позднескифской культуры склепов обнаружилось несколько (№ 734, 801, 871, 888, 907, 1031), имеющих короткий дромос между входной ямой и погребальной камерой. Дромосы совсем небольшие, еще меньше, чем в склепе № 158 Опушкинского могильника. Все остальные элементы погребального обряда, насколько можно судить по разграбленным погребальным сооружениям, типичны для позднескифской культуры. Датируются устьальминские склепы I в. до н.э. - первой половиной II в. н.э. Лишь в почти начисто разграбленном склепе № 801 обнаружены наконечник ремня и бусы, позволяющие датировать его второй половиной II - первой половиной
III в. н.э. ${ }^{11}$ [Пуздровский, Труфанов, 2016, с. 6063 , рис. $122-125 ; 2017$ a, с. $38,39,48,61$, рис. $83-$ $85,106,107,132 ; 20176$, с. $8,9,63$, рис. $3,4,131]$.

Результаты исследования склепа № 158 из могильника Опушки позволяют заключить, что не позже начала III в. н.э. в Крыму появились носители новых погребальных обрядов, включающих строительство склепов с короткими дромосами, иногда с подбоем в стене входной ямы. В подавляющем большинстве случаев погребенных укладывали в один ярус на дно погребальной камеры. Публикуемый склеп является исключением. В нем хоронили, согласно позднескифской традиции, в несколько не разделенных ярусов. На этом основании можно предположить, что мигранты интегрировали какую-то группу людей, сохранивших позднескифские погребальные обряды. Поиски истоков новых для Крыма традиций приводят к единственному более или менее удовлетворительному результату. Склепы с короткими дромосами появились на Северном Кавказе раньше, чем в Крыму, и использовались синхронно с крымскими [Храпунов, 2018a] ${ }^{12}$.

\section{ПРИМЕЧАНИЯ}

${ }^{1}$ Исследование выполнено при финансовой поддержке РФФИ в рамках научного проекта № 20-49-910003 «Исследования могильника Опушки в Крыму: итоги и перспективы».

The reported study was funded by RFBR, project number 20-49-910003 "Studies of the Opushki Cemetery in the Crimea: Results and Prospects."

${ }^{2}$ Антропологические определения сделаны В.И. Безбородых.

${ }^{3}$ Определение и описание монеты сделал Н.И. Храпунов.

${ }^{4}$ Благодарим С.Б. Шабанова за консультацию по хронологии стеклянного бальзамария.

${ }^{5}$ Информация о составе инвентаря предоставлена А.А. Труфановым, за что мы искренне ему признательны.

${ }^{6}$ Комплекс не опубликован.

${ }^{7}$ Близкие по составу наборы сопровождали два женских погребения в склепе № 17 Нейзацкого могильника с инвентарем второй половины II - первой половины III в. [Храпунов, Мульд, 2004, с. 300308], но количество бус в них значительно уступает наборам этого типа из других комплексов.

${ }^{8}$ Очень близкие по составу бус наборы имеются только в сарматских памятниках Венгерской 
низменности. Появившись, как и в Крыму, в середине II в. н.э., они используются в женском костюме альфельдских сарматов до IV в. включительно (подробнее см.: [Иштванович и др., 2020, с. 37]).

${ }^{9}$ Не следует, конечно, забывать, что склеп № 158 частично разграблен. В неразграбленном склепе лепных сосудов могло быть больше. Однако лепная керамика - это та категория погребального инвентаря, которая интересовала грабителей в последнюю очередь. Поэтому в разграбленных склепах IV в. н.э., как правило, находится множество целых и разбитых лепных сосудов.

${ }^{10}$ По наблюдениям С.А. Мульда, в могильнике Левадки во многих позднескифских склепах зафиксированы захоронения конца II - первой половины III в. н.э. [Мульд, 2011, с. 99], правда, опубликован пока самый необычный такой комплекс [Мульд, 2011], поэтому трудно понять, что собой представляли данные погребения.

${ }^{11}$ В Усть-Альминском могильнике известны и другие случаи, когда в склепах, сооруженных в раннеримское время, во второй половине II - первой половине III в. н.э. совершали новые погребения, иногда сопровождая этот обряд разграблением предшествующих захоронений [Пуздровский, 2014, c. 173; Пуздровский, Труфанов, 2015, с. 214-215].

${ }^{12} \mathrm{~B}$ связи с продолжающейся дискуссией о происхождении крымских склепов с короткими дромосами следует сказать о склепах из Чернореченского могильника. Они раскопаны давно, но до сих пор не привлекали внимания. Сторонники независимого возникновения северокавказских и крымских склепов, перечисляя их отличия, указывали на большее в Крыму количество погребенных и на то, что на Кавказе погребенные лежали вдоль длинной оси погребальной камеры, а в Крыму поперек [Мошкова, Малашев, 1999, с. 195-197]. В могильнике на Черной речке склепы № 1 и 4 предназначались для одного погребенного, № 3 и 5 - для двух, № 4 - для четырех (остальные склепы разграблены так, что количество погребенных установить нельзя). Во всех без исключения случаях погребенные лежали, как на Северном Кавказе, вдоль длинной оси погребальной камеры [Бабенчиков, 1963, c. 113-119]. Заметим также, что в склепах расположенного неподалеку от Чернореченского могильника Фронтовое 3, где хоронили от 1 до 6 человек, зафиксированы оба варианта положения погребенных: и вдоль и поперек длинной оси погребальной камеры [Свиридов, Язиков, 2019, с. 193-195]. Вдоль длинной оси погребальной камеры лежат погребенные (двое взрослых и ребенок) в единственном раскопанном склепе могильника Бельбек III. Входная яма, как у поздних скифов, была забита камнями единственный такой пример для крымских склепов позднеримского времени [Филиппенко и др., 2016]. 


\section{ИЛЛЮСТРАЦИИ}

\section{Таблица 1. Бусы и подвески из склепа № 158}

Table 1. Beads and pendants from vault no. 158

\begin{tabular}{|c|c|c|c|c|c|c|c|c|c|c|c|c|c|c|c|c|c|}
\hline \multirow{2}{*}{$\begin{array}{c}\text { № } \\
\text { I/II }\end{array}$} & \multirow{2}{*}{$\begin{array}{c}\text { Описание типа / } \\
\text { № погребения } \\
\text { и месторасположение }\end{array}$} & \multirow[b]{2}{*}{ 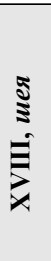 } & \multirow[b]{2}{*}{ 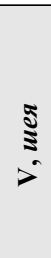 } & \multirow[b]{2}{*}{ 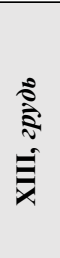 } & \multirow[b]{2}{*}{$\begin{array}{l}\stackrel{0}{\grave{2}} \\
\bar{\Sigma}\end{array}$} & \multicolumn{3}{|c|}{ IV } & \multirow[b]{2}{*}{ 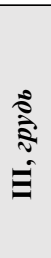 } & \multirow[b]{2}{*}{$\begin{array}{l}\stackrel{5}{\vdots} \\
= \\
=\end{array}$} & \multicolumn{3}{|c|}{ I } & \multirow[b]{2}{*}{ 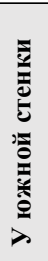 } & \multirow[b]{2}{*}{ 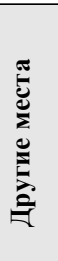 } & \multirow[b]{2}{*}{$\stackrel{\mathscr{E}}{\mathscr{0}}$} & \multirow[b]{2}{*}{$\stackrel{*}{E}$} \\
\hline & & & & & & $\stackrel{\tilde{\Xi}}{\Xi}$ & ثิ & $\stackrel{\Xi}{\cong}$ & & & 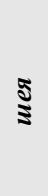 & $\frac{\sqrt{5}}{3}$ & 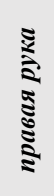 & & & & \\
\hline \multicolumn{18}{|c|}{ ОДНОЦВЕТНОЕ СТЕКЛО } \\
\hline 1 & \begin{tabular}{|l} 
Цилиндрические, \\
глухое красное \\
(рис. 8,6,12,16,18, \\
$9,1,9,12,19,24,26$, \\
10,10 )
\end{tabular} & 2 & 3 & & 5 & & & 146 & & 1 & & 14 & 28 & 7 & 83 & 289 & 57 \\
\hline 2 & \begin{tabular}{|l} 
Цилиндрические, \\
глухое белое \\
(рис. $8,7,17,9,8,11$, \\
$18,23,25,10,11$ )
\end{tabular} & & & & 1 & & & 68 & & 1 & & 7 & 11 & 3 & 50 & 137 & 55 \\
\hline 3 & $\begin{array}{l}\text { Цилиндрическая, } \\
\text { прозрачное синие } \\
\text { (рис. 8,19) }\end{array}$ & & & & & & & 1 & & & & & & & & 1 & 68 \\
\hline 4 & $\begin{array}{l}\text { Цилиндрическая, } \\
\text { прозрачное темно- } \\
\text { лиловое (рис. } 8,21 \text { ) }\end{array}$ & & & & & & & 1 & & & & & & & & 1 & 59 \\
\hline 5 & \begin{tabular}{|l|} 
Цилиндрические, \\
прозрачное зеленое \\
(рис. 8,20)
\end{tabular} & & & & & & & 2 & & & & & & & & 2 & 63 \\
\hline 6 & $\begin{array}{l}\text { Короткоцилиндри- } \\
\text { ческая с косыми } \\
\text { торцами, полупро- } \\
\text { зрачное бирюзовое } \\
\text { (рис. } 8,24 \text { ) }\end{array}$ & & & & & & & 1 & & & & & & & & 1 & 66 \\
\hline 7 & $\begin{array}{l}\text { Призматические, } \\
\text { глухое красное } \\
\text { (рис. } 8,23,9,13,10,13 \text { ) }\end{array}$ & & & & & & & 11 & & & & & 1 & & 8 & 20 & 117 \\
\hline 8 & $\begin{array}{l}\text { Бочковидная попе- } \\
\text { речно сжатая, глухое } \\
\text { белое (рис. } 10,16 \text { ) }\end{array}$ & & & & & & & & & & & & & & 1 & 1 & 21 \\
\hline 9 & $\begin{array}{l}\text { Призматические, } \\
\text { прозрачное темно- } \\
\text { зеленое (рис. } 8,8,22, \\
9,14,30,10,17 \text { ) }\end{array}$ & & & & 1 & 1 & & 15 & & & & & 1 & & 3 & 21 & 120 \\
\hline 10 & $\begin{array}{l}\text { Призматическая, } \\
\text { глухое зеленое } \\
\text { (рис. } 10,12 \text { ) }\end{array}$ & & & & & & & & & & & & & & 1 & 1 & - \\
\hline 11 & $\begin{array}{l}\text { Призматическая, } \\
\text { прозрачное синее } \\
\text { (рис. 9,10) }\end{array}$ & & & & & & & & & & & 1 & & & & 1 & - \\
\hline 12 & $\begin{array}{l}\text { Призматические, } \\
\text { прозрачное темно- } \\
\text { лиловое (рис. } 8,26, \\
10,14 \text { ) }\end{array}$ & & & & & & & 18 & & & & 1 & & & 4 & 23 & 118 \\
\hline 13 & $\begin{array}{l}\text { 14-гранные, про- } \\
\text { зрачное зеленое } \\
\text { (рис. } 8,33,10,21) \\
\end{array}$ & & & & & & & 5 & & & & & & & 4 & 9 & 131 \\
\hline
\end{tabular}

Примечание. * - типы бус даны по классификации Е.М. Алексеевой [Алексеева, 1975; 1978; 1982]. 
Продолжение таблищь 1

Continuation of Table 1

\begin{tabular}{|c|c|c|c|c|c|c|c|c|c|c|c|c|c|c|c|c|c|}
\hline \multirow{2}{*}{$\begin{array}{c}\text { № } \\
\text { II/II }\end{array}$} & \multirow{2}{*}{$\begin{array}{c}\text { Описание типа / } \\
\text { № погребения } \\
\text { и месторасположение }\end{array}$} & \multirow[b]{2}{*}{ 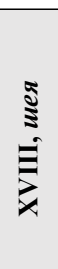 } & \multirow[b]{2}{*}{$\underset{\substack{\tilde{S} \\
>}}{>}$} & \multirow[b]{2}{*}{ 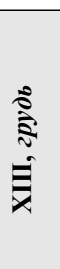 } & \multirow[b]{2}{*}{ 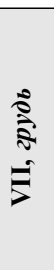 } & \multicolumn{3}{|c|}{ IV } & \multirow[b]{2}{*}{ 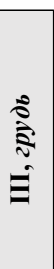 } & \multirow[b]{2}{*}{$\begin{array}{l}\overrightarrow{0} \\
\stackrel{5}{2} \\
=\end{array}$} & \multicolumn{3}{|c|}{ I } & \multirow[b]{2}{*}{ 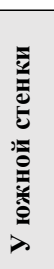 } & \multirow[b]{2}{*}{$\begin{array}{l}\frac{\pi}{0} \\
\frac{0}{2} \\
0 \\
0 \\
0 \\
0\end{array}$} & \multirow[b]{2}{*}{ 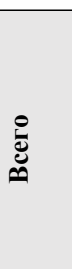 } & \multirow[b]{2}{*}{$\stackrel{*}{\Xi}$} \\
\hline & & & & & & 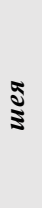 & ڤิ & 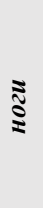 & & & 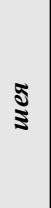 & 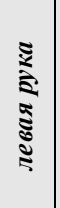 & 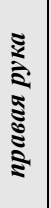 & & & & \\
\hline \multicolumn{18}{|c|}{ ОДНОЦВЕТНОЕ СТЕКЛО } \\
\hline 14 & \begin{tabular}{|l|} 
14-гранные, про- \\
зрачное темно-лило- \\
вое (рис. 8,29 ) \\
\end{tabular} & & & & & & & 3 & & & & & & & & 3 & 128 \\
\hline 15 & $\begin{array}{l}\text { 14-гранные, полу- } \\
\text { прозрачное синее } \\
\text { (рис. } 8,27 \text { ) }\end{array}$ & & & & & & & 2 & & & & & 2 & & & 4 & 134 \\
\hline 16 & $\begin{array}{l}\text { Бочковидные попе- } \\
\text { речно сжатые, про- } \\
\text { зрачное желтое } \\
\text { (рис. } 8,35 \text { ) } \\
\end{array}$ & & & & & & & 5 & & & & & & & & 5 & 23 \\
\hline 17 & $\begin{array}{l}\text { Бочковидные, про- } \\
\text { зрачное розовое } \\
\text { (рис. } 8,25,10,20 \text { ) } \\
\end{array}$ & & & & & & & 2 & & & & & & & 1 & 3 & - \\
\hline 18 & $\begin{array}{l}\text { Шаровидная, про- } \\
\text { зрачное зеленое } \\
\text { (рис. 10,15) } \\
\end{array}$ & & & & & & & & & & & & & & 1 & 1 & 8 \\
\hline 19 & $\begin{array}{l}\text { В форме параллеле- } \\
\text { пипеда, прозрачное } \\
\text { зеленое (рис. } 8,28, \\
10,18 \text { ) } \\
\end{array}$ & & & & & & & 6 & & & & & & & 1 & 7 & - \\
\hline 20 & $\begin{array}{l}\text { В форме плоского } \\
\text { диска, полупрозрач- } \\
\text { ное и глухое синее } \\
\text { (рис. } 9,2,5,10,22 \text { ) } \\
\end{array}$ & & & & & & & & & & 1 & & & & 2 & 3 & 75 \\
\hline 21 & $\begin{array}{l}\text { Линзовидные, про- } \\
\text { зрачное темно-лило- } \\
\text { вое (рис. } 8,4,10,19 \text { ) }\end{array}$ & & & & & & 2 & & & & & & & & 1 & 3 & 84 \\
\hline \multicolumn{11}{|c|}{ Всего из одноцветного стекла } & & & & & & 540 & \\
\hline \multicolumn{18}{|c|}{ МНОГОЦВЕТНОЕ СТЕКЛО } \\
\hline 22 & \begin{tabular}{|l|} 
Бочковидная \\
(рис. 9,21) и шаро- \\
видная поперечно \\
сжатые (рис. 8,9) из \\
глухого черного \\
стекла. Украшены \\
мелкими пятнышка- \\
ми из глухого жел- \\
того, красного, бело- \\
го, зеленого и голу- \\
бого стекла \\
\end{tabular} & & & 1 & & & & & & 1 & & & & & & 2 & 13 \\
\hline 23 & $\begin{array}{l}\text { Бочковидная из глу- } \\
\text { хого зеленого стекла, } \\
\text { украшенная семью } \\
\text { глазками, в который } \\
\text { центральный диск из } \\
\text { прозрачного синего } \\
\text { стекла окружен од- } \\
\text { ним кольцом из глу- } \\
\text { хого черного стекла } \\
\text { и двумя кольцами из } \\
\text { глухого белого стек- } \\
\text { ла (рис. 9,29) } \\
\end{array}$ & & & & & & & & 1 & & & & & & & 1 & - \\
\hline
\end{tabular}




\section{Продолжение таблищь 1}

\section{Continuation of Table 1}

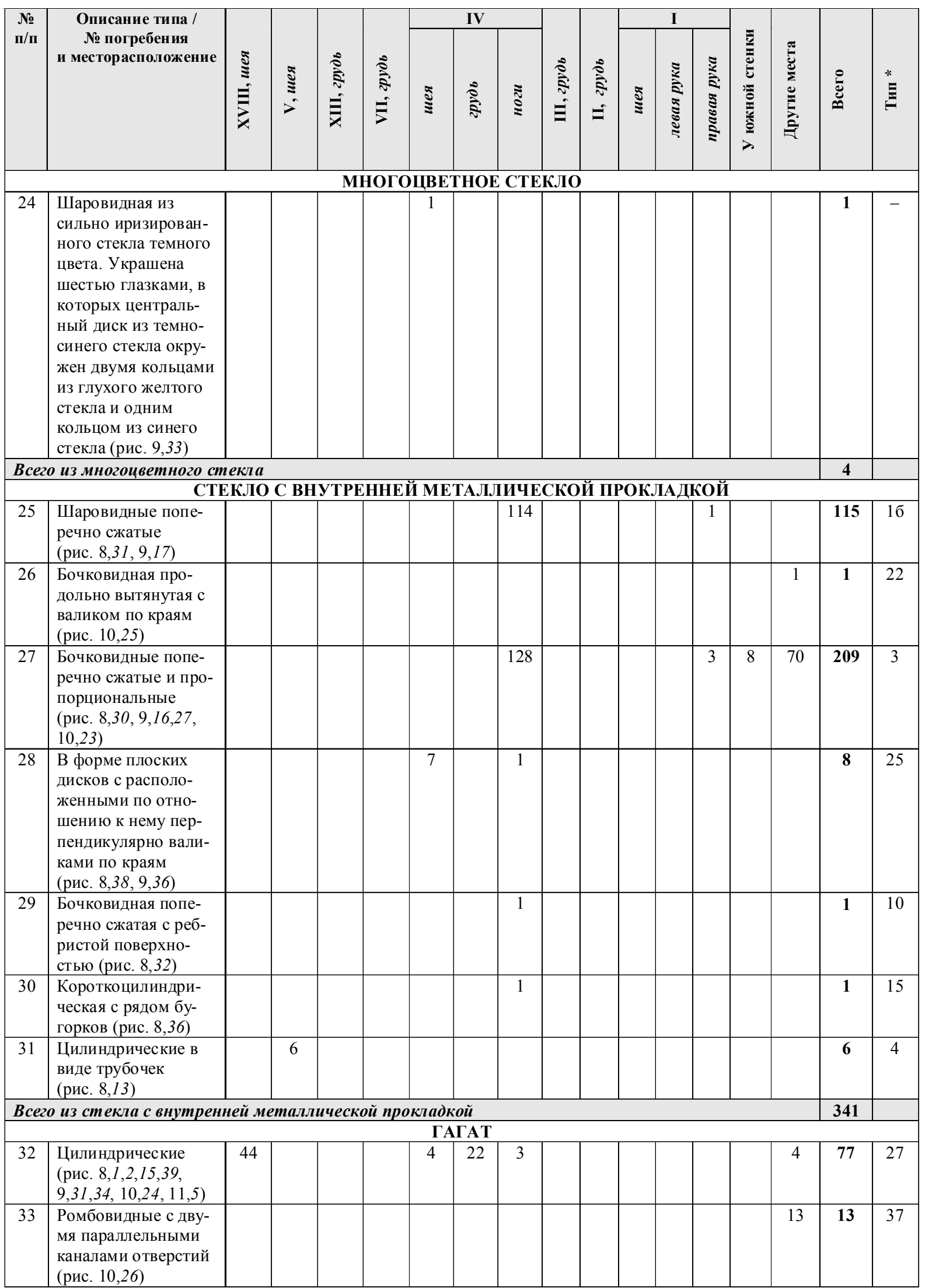


Окончание таблицы 1

End of Table 1

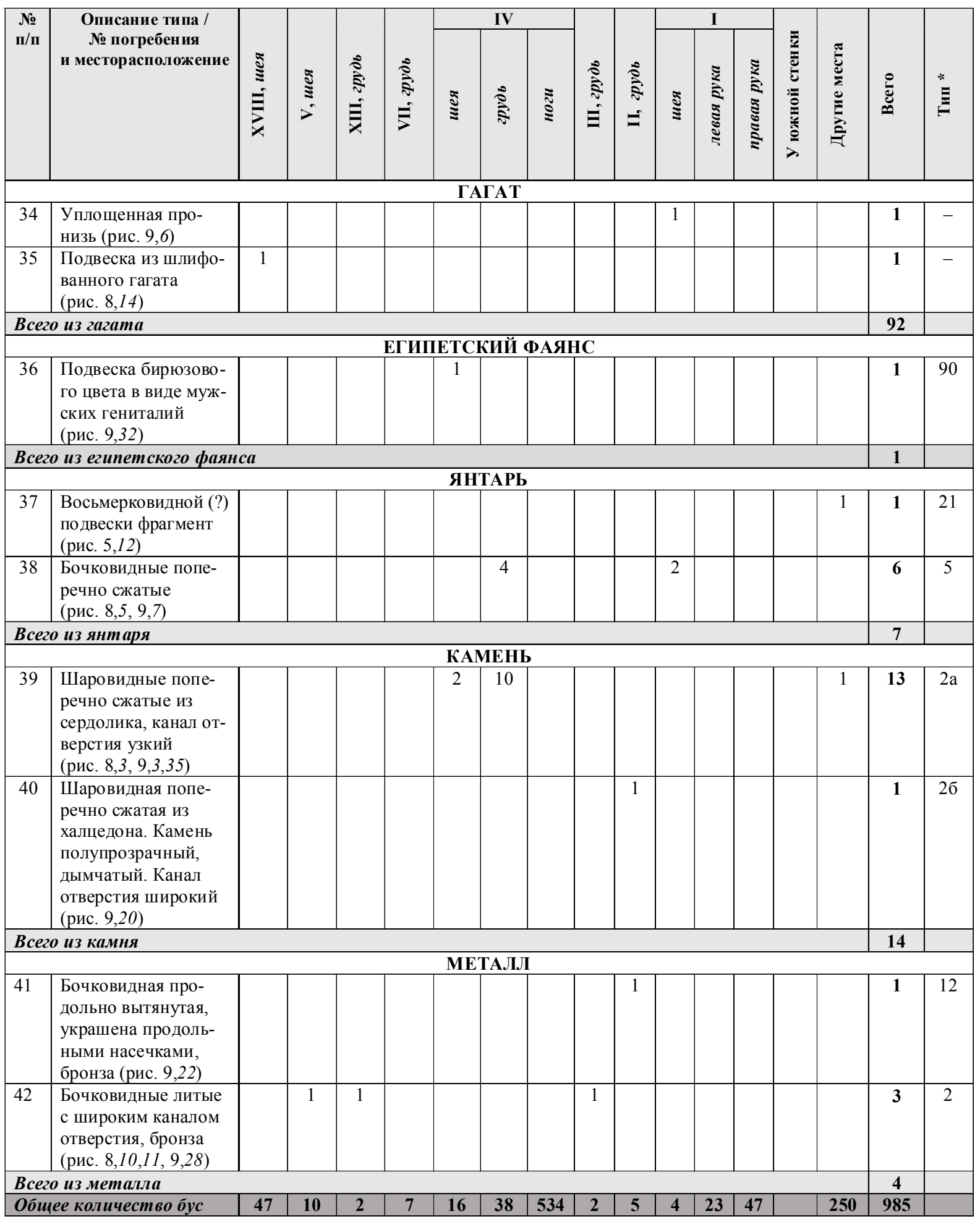




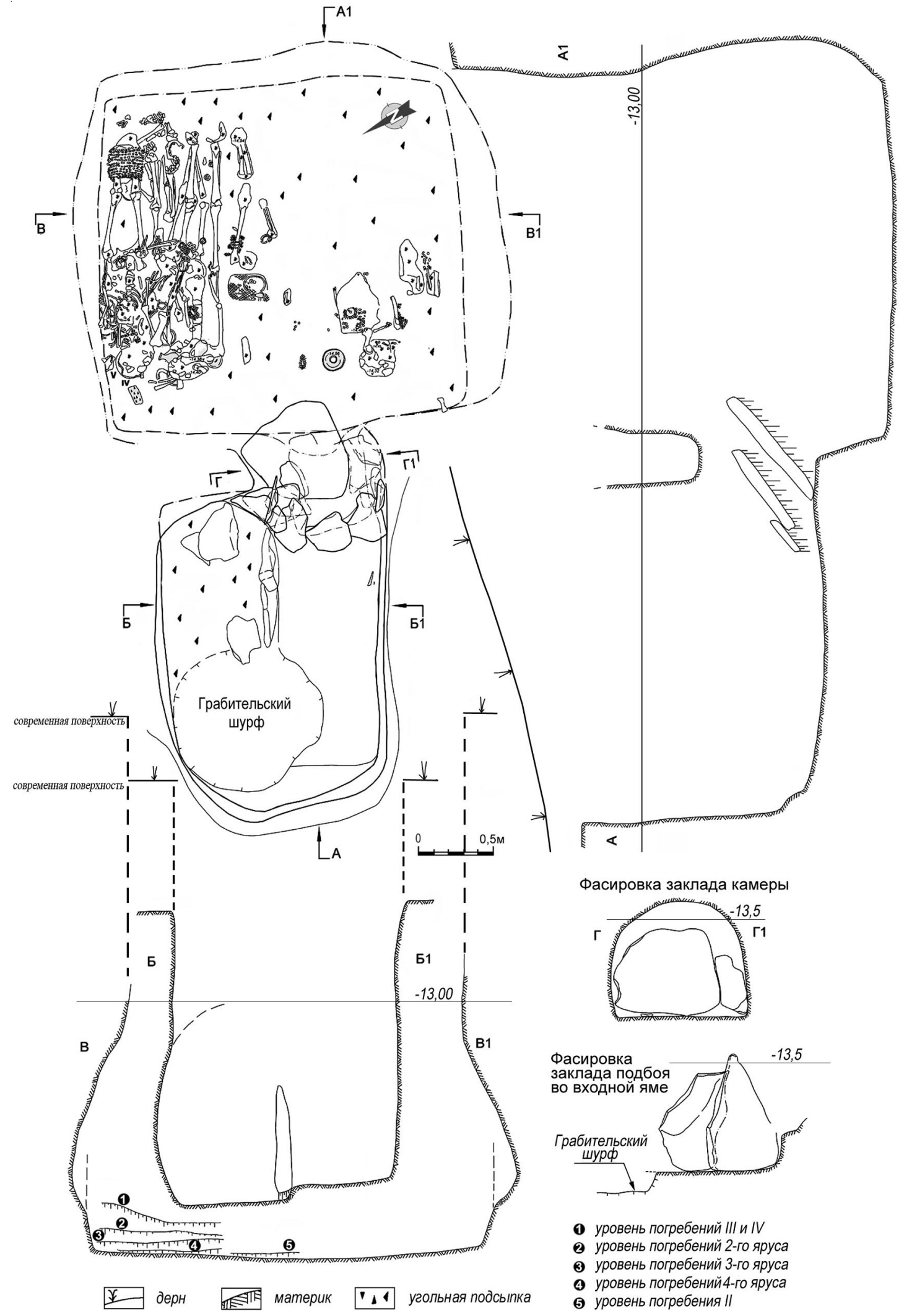

Рис. 1. Могильник Опушки, склеп № 158. План, разрезы и фасировки каменных закладов (чертеж А.А. Стояновой)

Fig. 1. The cemetery of Opushki, burial vault no. 158. Ground plan, cross-sections, and projections of stone barriers (drawing by A.A. Stoyanova) 

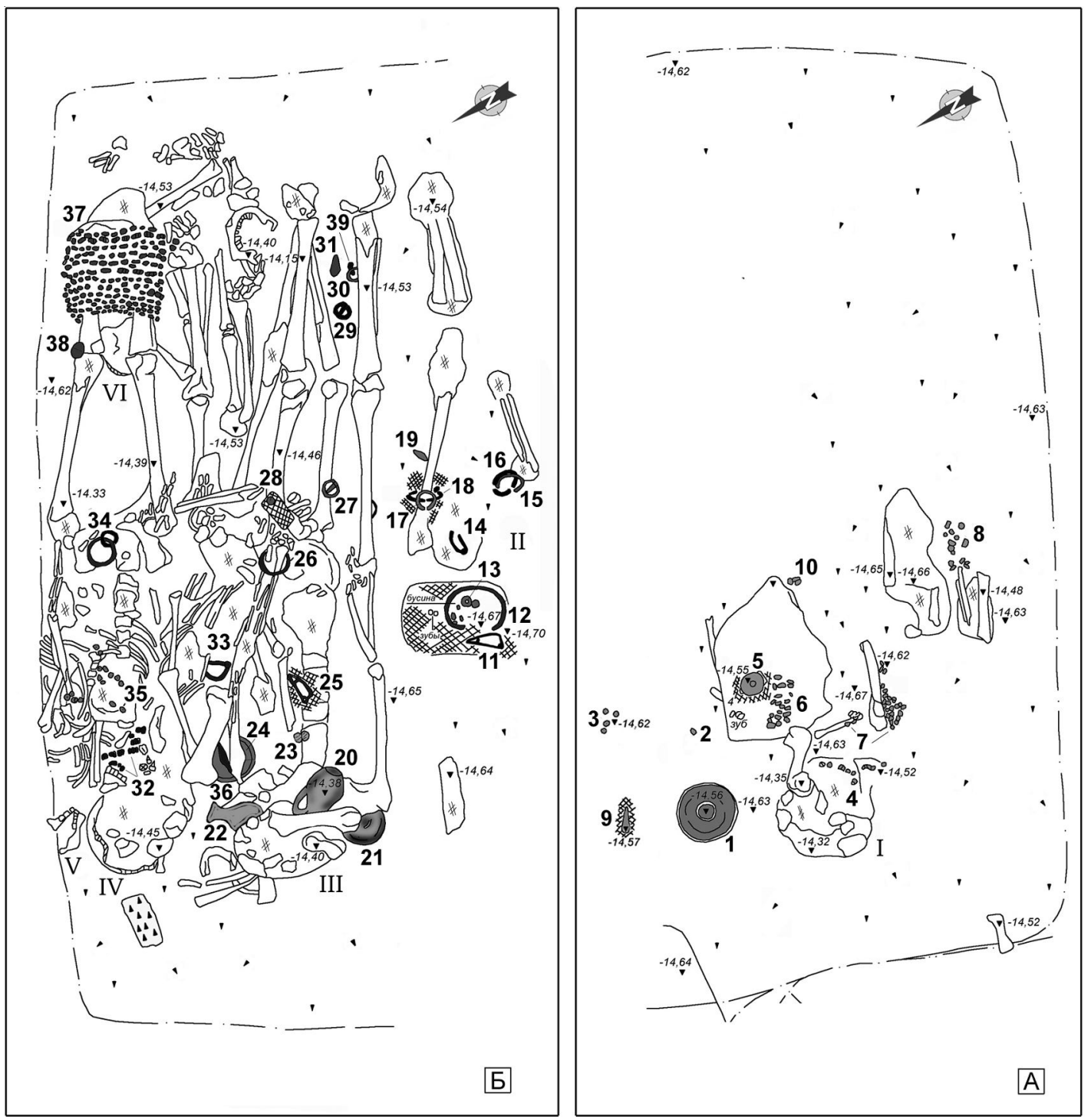

$\mathrm{I}-\mathrm{VI}$ номера погребений
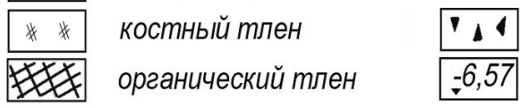

угольная подсыпка

высотнье отметки

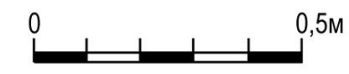

Рис. 2. Могильник Опушки, склеп № 158. План погребений в камере (чертеж А.А. Стояновой):

$A$ - остатки погребений в южной части камеры: 1 - миска краснолаковая; 2-4, 6-8, 10 - бусы; 5 - предмет бронзовый со стеклянной вставкой; 9 - нож железный.

5 - погребения в северной части камеры: $11,25,33$ - фибулы бронзовые; 12 - гривна бронзовая;

$13,23,32,35,37$ - бусы; 14 - фибула железная; $15,17,18,26$ - браслеты бронзовые; 16 - браслет железный;

19 - предмет железный; 20 - кувшин лепной; 21,24 - тарелки краснолаковые; 22 - кувшин краснолаковый;

27, 29 - пряжки; 28 - монета; 30 - кольцо бронзовое; 31 - отщеп кремневый; 34 - браслет с перстнем бронзовые; 36 - нож железный; 38 - пряслице керамическое; 39 - астрагал

Fig. 2. The cemetery of Opushki, burial vault no. 158. Ground plan of the burials in the chamber (drawing by A.A. Stoyanova):

$A$ - remains of the burials in the southern area of the chamber: 1 - red slip bowl; 2-4, 6-8, 10 - beads; 5 - bronze artefact with glass inset; 9 - iron knife.

5 - burials in the northern area of the chamber: $11,25,33$ - bronze brooches; 12 - bronze neck-ring;

13, 23, 32, 35, 37 - beads; 14 - iron brooch; 15, 17, 18, 26 - bronze bracelets; 16 - iron bracelet;

19 - iron artefact; 20 - hand-made pitcher; 21,24 - red-slip plates; 22 - red-slip pitcher;

27, 29 - buckles; 28 - coin; 30 - bronze ring; 31 - flint flake; 34 - bronze bracelet and finger-ring; 36 - iron knife; 38 - ceramic spindle whorl; 39 - knucklebone 

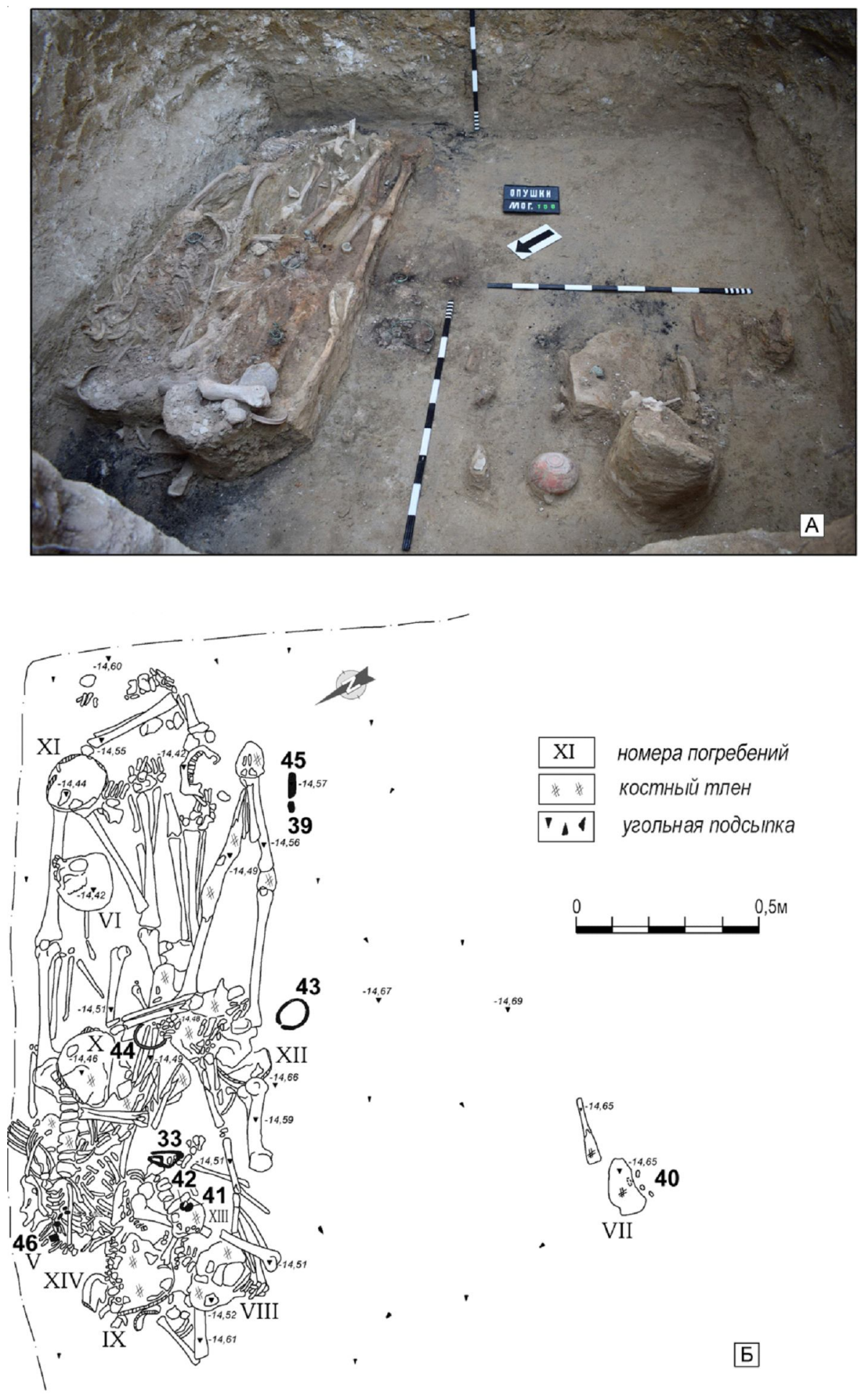

Рис. 3. Могильник Опушки, склеп № 158:

$A$ - погребения в камере (фото А.А. Стояновой).

$Б$ - план погребений второго яруса в северной части (чертеж А.А. Стояновой): 33 - фибула бронзовая; 39 - астрагал; 40, 41, 46 - бусы; 42 - кольцо бронзовое; 43, 44 - браслеты бронзовые; 45 - оселок каменный

Fig. 3. The cemetery of Opushki, burial vault no. 158:

$A$ - burials in the chamber (photo by A.A. Stoyanova).

$B$ - ground plan of the second tier of burials in the northern area (drawing by A.A. Stoyanova): 33 - bronze brooch; 39 - knucklebone; 40, 41, 46 - beads; 42 - bronze ring; 43,44 - bronze bracelets; 45 - sharpening stone 
И.Н. Храпунов, А.А. Стоянова. Склеп с многократными погребениями III в. н.э. из могильника Опушки
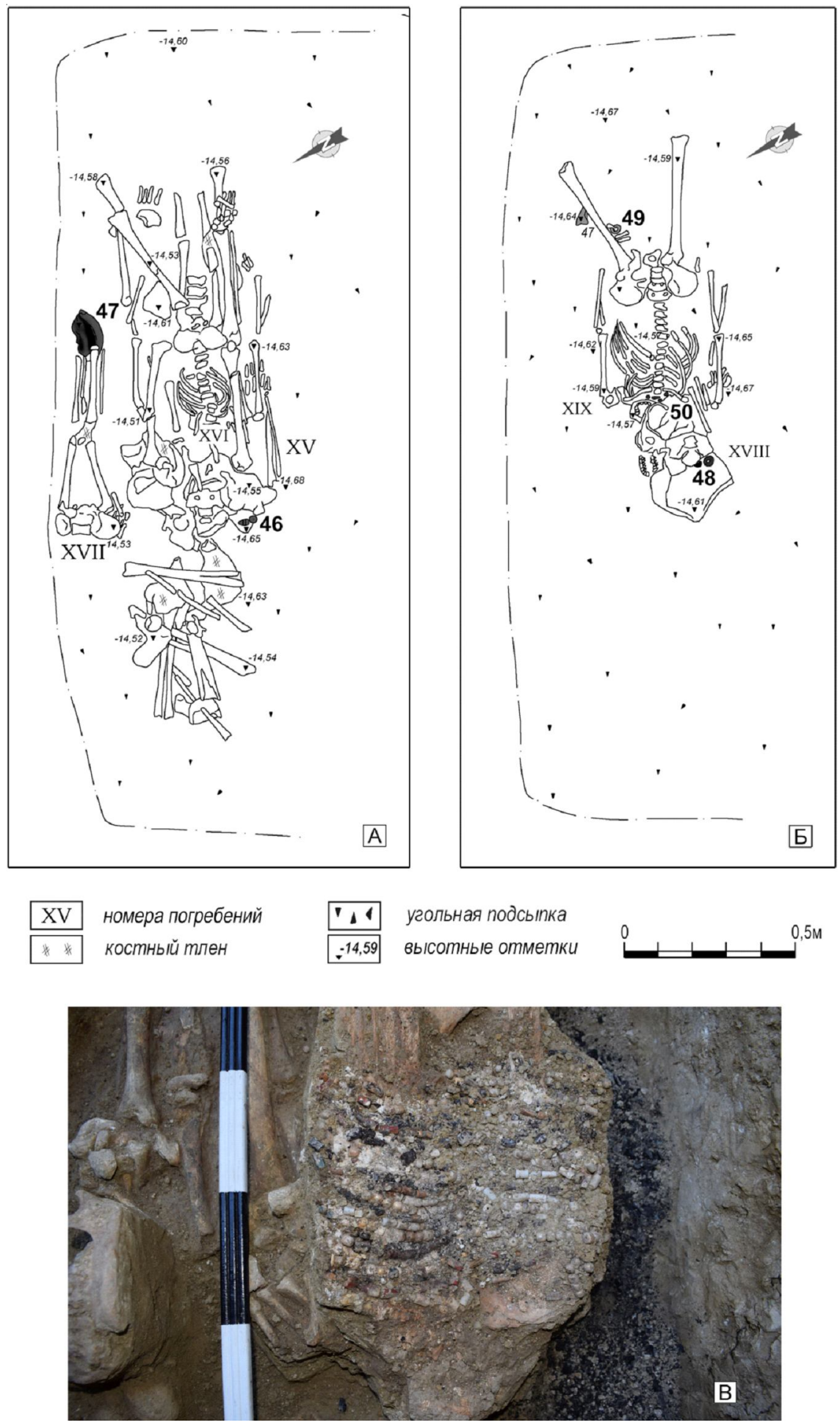

Рис. 4. Могильник Опушки, склеп № 158 (чертеж, фото А.А. Стояновой):

$A$ - погребение третьего яруса: 46 - бусы; 47 - фрагмент краснолаковой миски.

$Б$ - погребение четвертого яруса: 48 - пряслице керамическое; 49 - кольцо бронзовое; 50 - бусы. $B$ - набор бус на берцовых костях погребения IV

Fig. 4. The cemetery of Opushki, burial vault no. 158 (drawing and photo by A.A. Stoyanova): $A$ - burial of the third tier: 46 - beads, 47 - red slip bowl fragment.

5 - burial of the fourth tier: 48 - ceramic spindle whorl, 49 - bronze ring, 50 - beads. $B$ - set of beads on shinbones of burial IV 


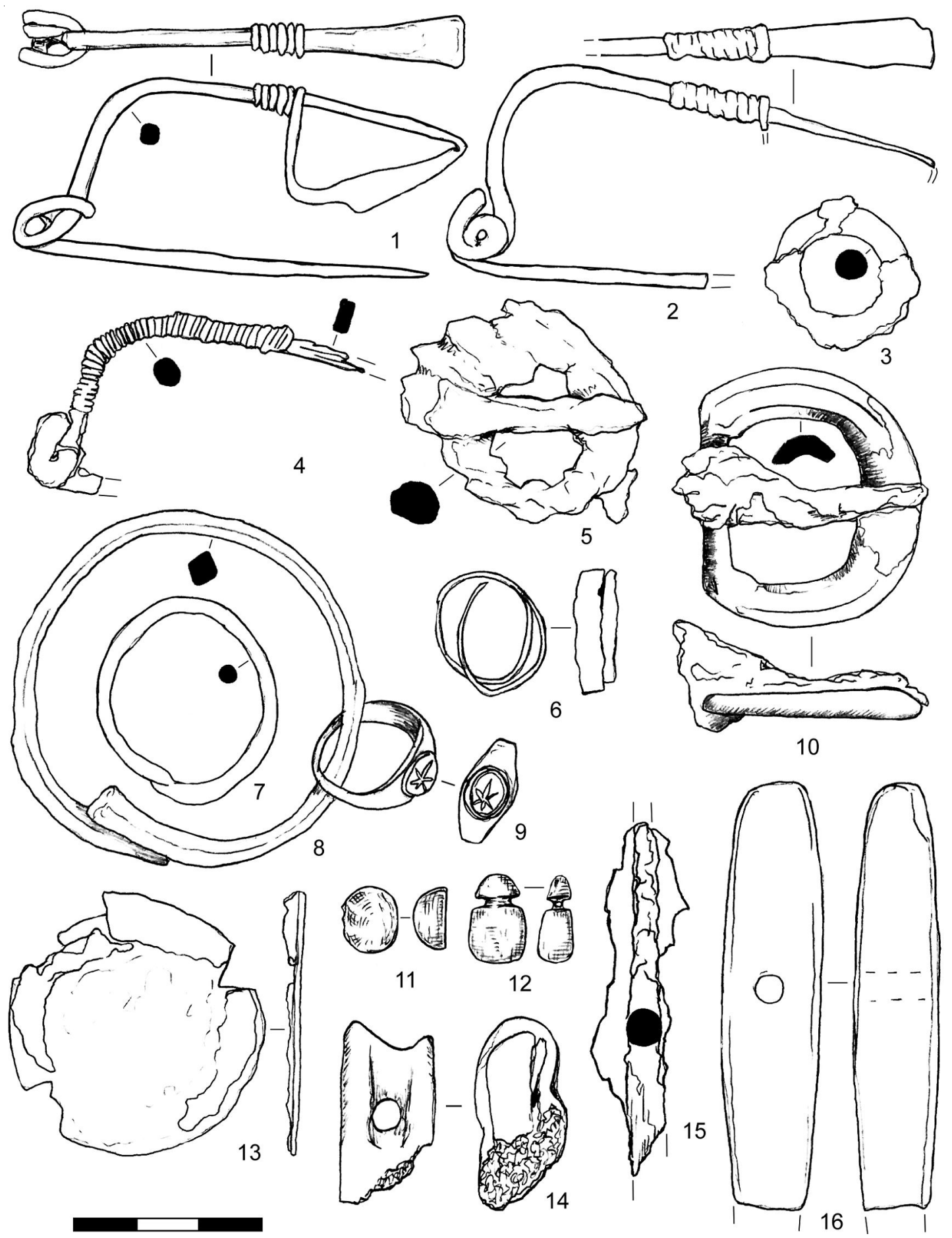

Рис. 5. Могильник Опушки, склеп № 158. Погребальный инвентарь (рис. С.Б. Шабанова):

1,2, 4 - фибулы бронзовые; 3, 6, 7 - кольца бронзовые; 5, 10 - пряжки железная и бронзовая; 8 - браслет бронзовый; 9 - перстень бронзовый; 11 - вставка стеклянная; 12 - подвеска из янтаря;

13 - дисковидный бронзовый предмет; 14 - астрагал; 15 - фрагмент железного предмета; 16 - оселок каменный

Fig. 5. The cemetery of Opushki, burial vault no. 158. Grave goods (drawing by S.B. Shabanov):

1,2, 4- bronze brooches; 3, 6, 7- bronze rings; 5, 10 - iron and bronze buckles;

8 - bronze bracelet; 9 - bronze finger-ring; 11 - glass inset; 12 - amber pendant;

13 - bronze disc-shaped artefact; 14 - knucklebone; 15 - iron fragment of an artefact; 16 - stone whetstone 

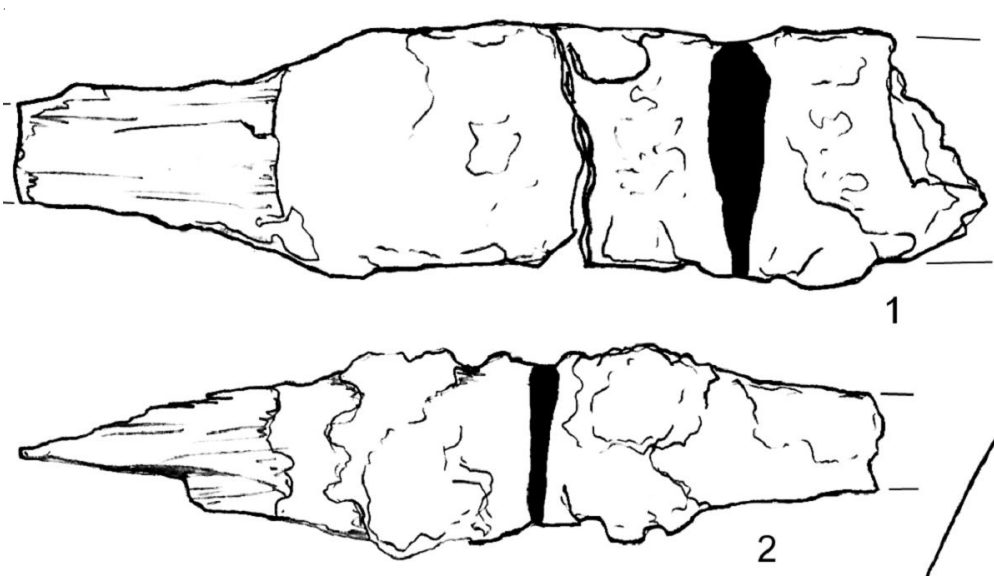

1
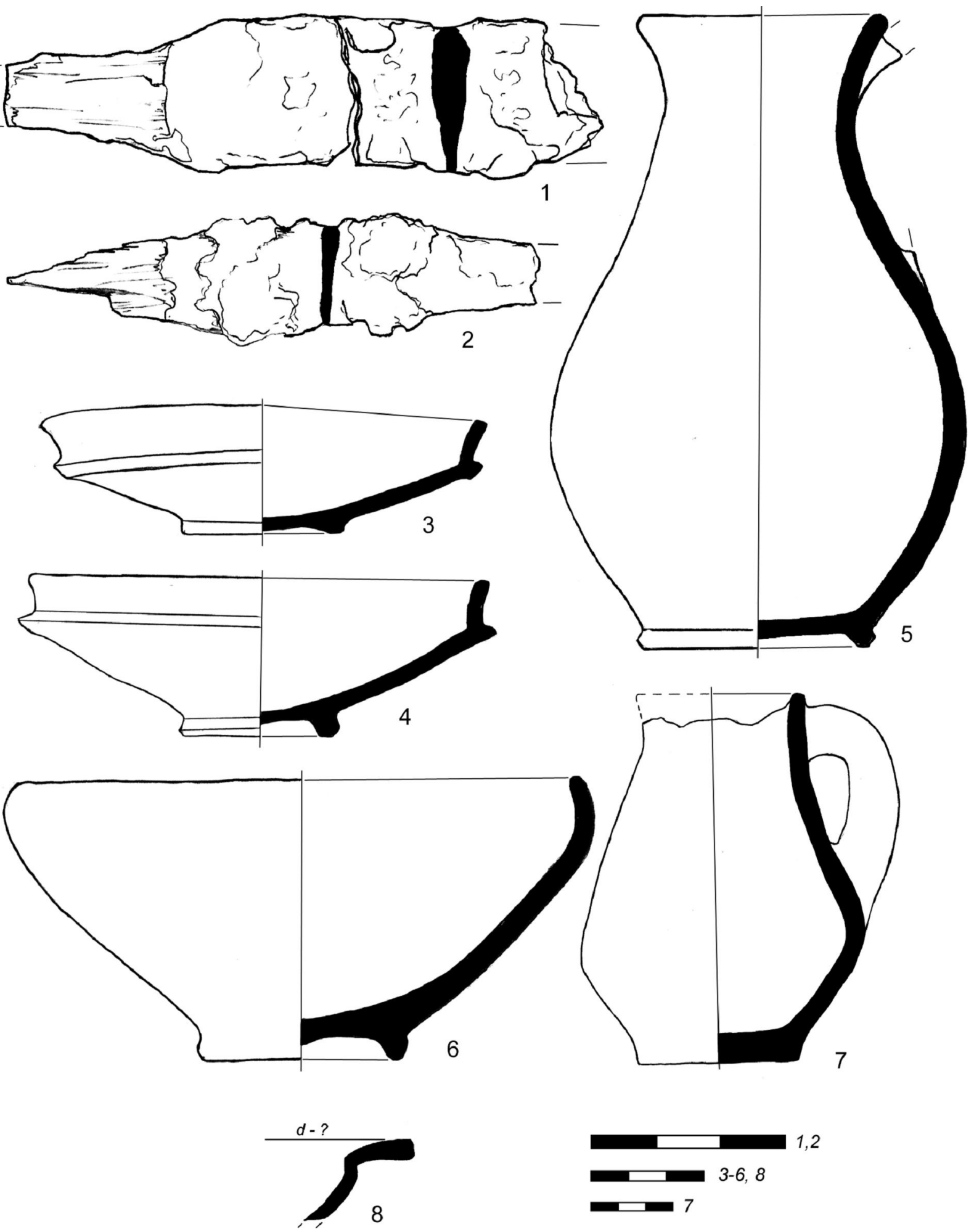

6

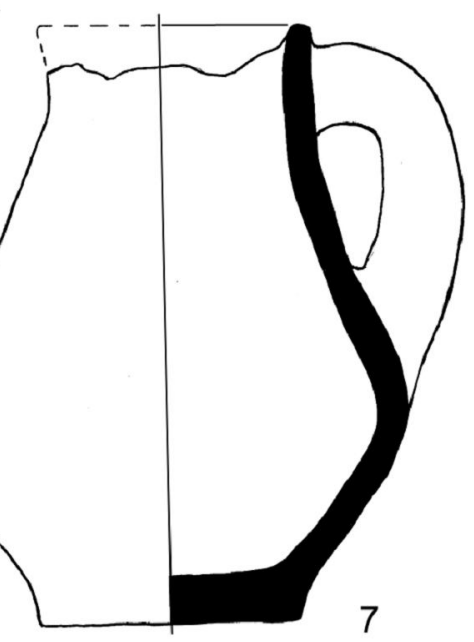

Рис. 6. Могильник Опушки, склеп № 158. Погребальный инвентарь (рис. С.Б. Шабанова):

1, 2 - ножи железные; 3, 4 - тарелки краснолаковые; 5 - кувшин краснолаковый;

6 - миска краснолаковая; 7 - кувшин лепной; 8 - фрагмент краснолаковой миски

Fig. 6. The cemetery of Opushki, burial vault no. 158. Grave goods (drawing by S.B. Shabanov):

1,2 - iron knives; 3, 4 - red slip plates; 5 - red slip pitcher;

6 - red slip bowl; 7 - moulded pitcher; 8 - red slip bowl fragment 


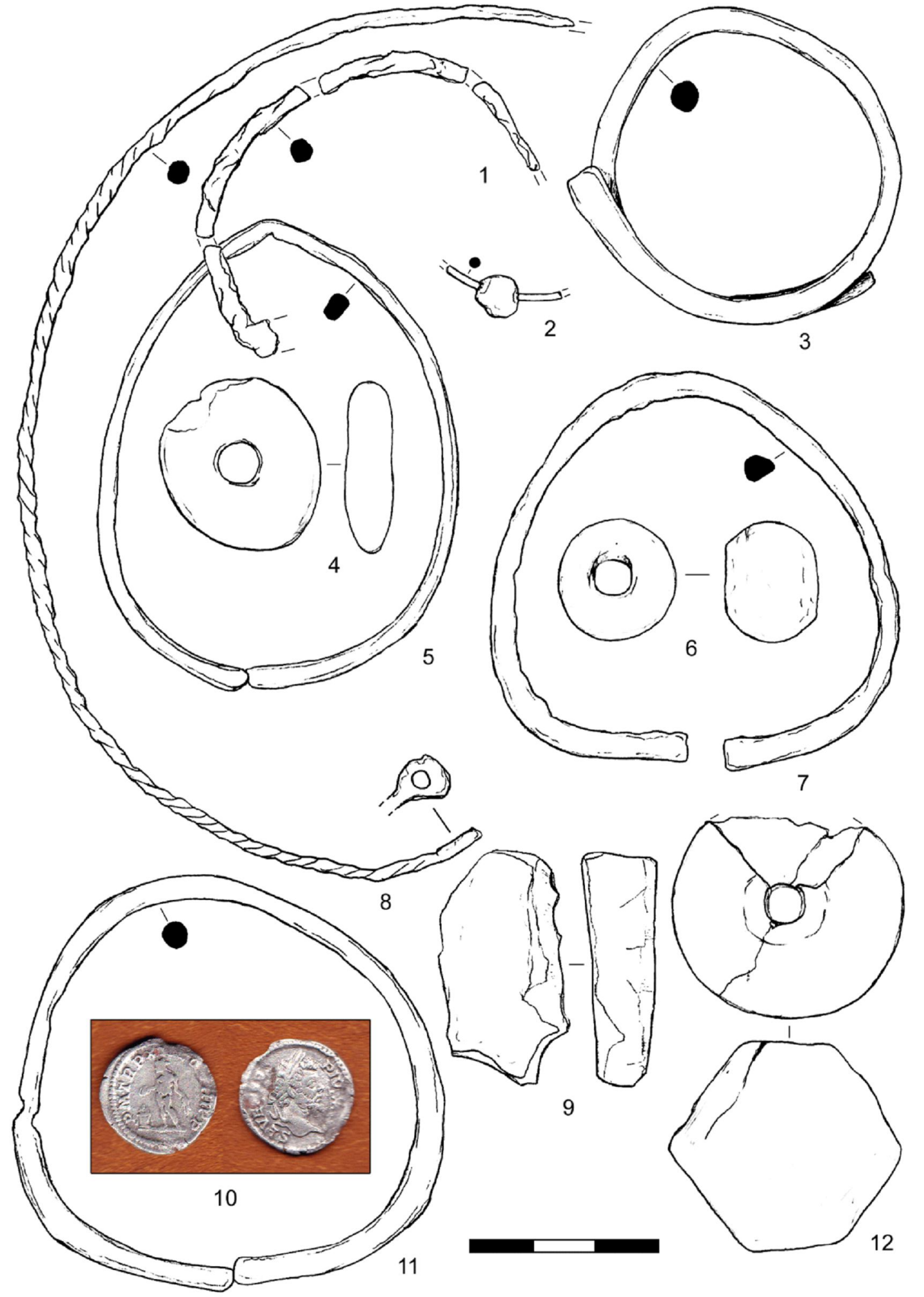

Рис. 7. Могильник Опушки, склеп № 158. Погребальный инвентарь (рис. С.Б. Шабанова):

1 - браслет железный; 2, 3, 5, 7, 11 - браслеты бронзовые; 4 - пряслице керамическое; 6 - пронизь бронзовая; 8 - гривна бронзовая; 9 - отщеп кремневый; 10 - монета серебряная; 12 - пряслице керамическое

Fig. 7. The cemetery of Opushki, burial vault no. 158. Grave goods (drawing by S.B. Shabanov):

1 - iron bracelet; $2,3,5,7,11$ - bronze bracelets; 4 - ceramic spindle whorl; 6 - bronze bead; 8 - bronze neck-ring; 9 - flint flake; 10 - silver coin; 12 - ceramic spindle whorl 
И.Н. Храпунов, А.А. Стоянова. Склеп с многократными погребениями III в. н.э. из могильника Опушки

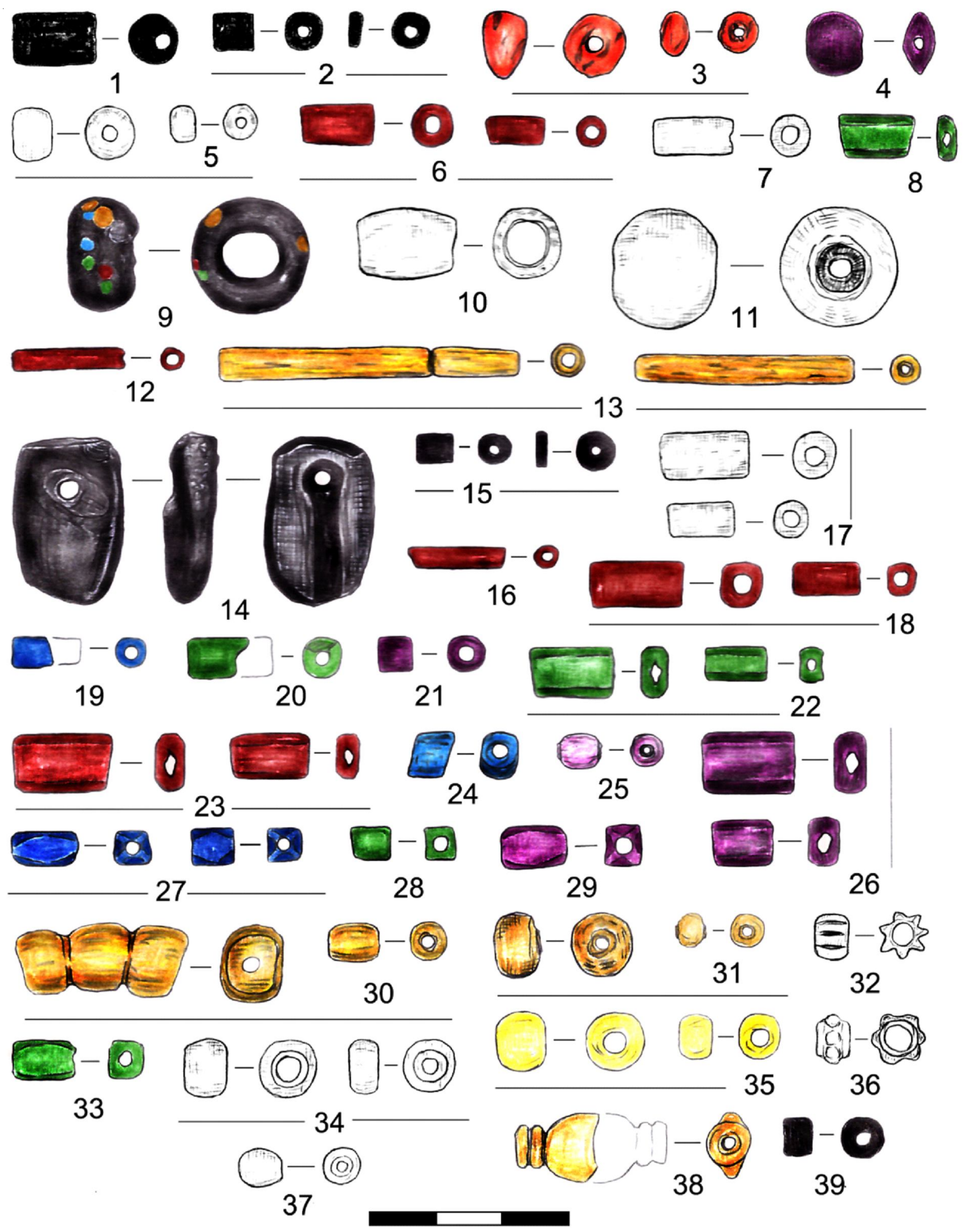

Рис. 8. Могильник Опушки, склеп № 158. Погребальный инвентарь. Бусы (рис. А.А. Стояновой): 1-5 - погребение IV; 6-8 - погребение VII; 9, 10 - погребение XIII; 11-13 - погребение V; 14-16 - погребение XVIII; 17-39 - погребение IV

Fig. 8. The cemetery of Opushki, burial vault no. 158. Grave goods. Beads (drawing by A.A. Stoyanova): 1-5 - burial IV; 6-8 - burial VII; 9, 10 - burial XIII; 11-13 - burial V; 14-16 - burial XVIII; $17-39$ - burial IV 
I.N. Khrapunov, A.A. Stoyanova. A Third Century AD Burial Vault with Multiple Burials at the Cemetery of Opushki

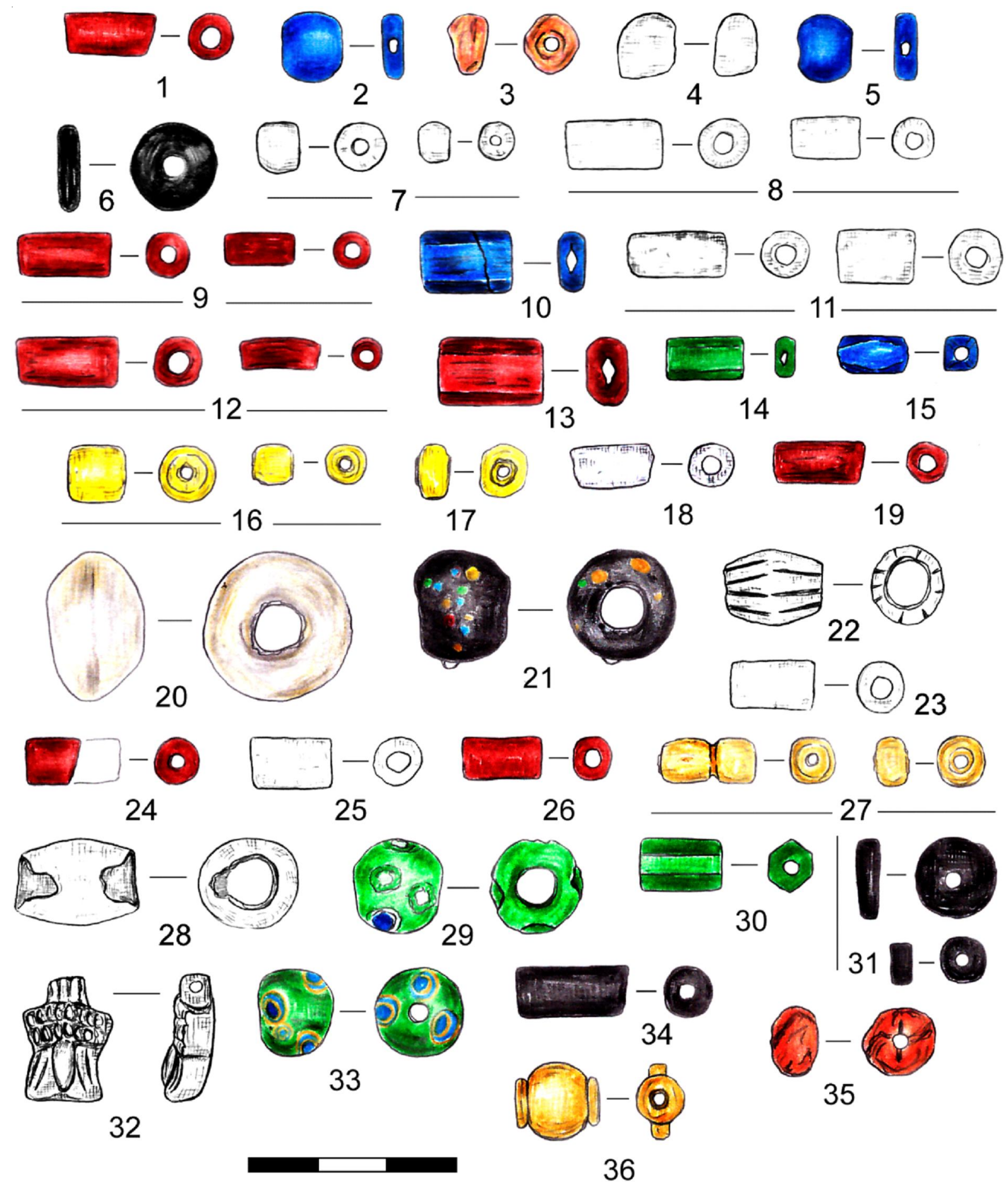

Рис. 9. Могильник Опушки, склеп № 158. Погребальный инвентарь. Бусы и подвески (рис. А.А. Стояновой): 1-19, 25-27 - погребение I и южная часть камеры; 20-24 - погребение II; 28, 29 - погребение III; 30-36 - погребение IV

Fig. 9. The cemetery of Opushki, burial vault no. 158. Grave goods. Beads and pendants (drawing by A.A. Stoyanova): 1-19, 25-27 - burial I and the southern area of the chamber; 20-24 - burial II; 28, 29 - burial III; 30-36 - burial IV 


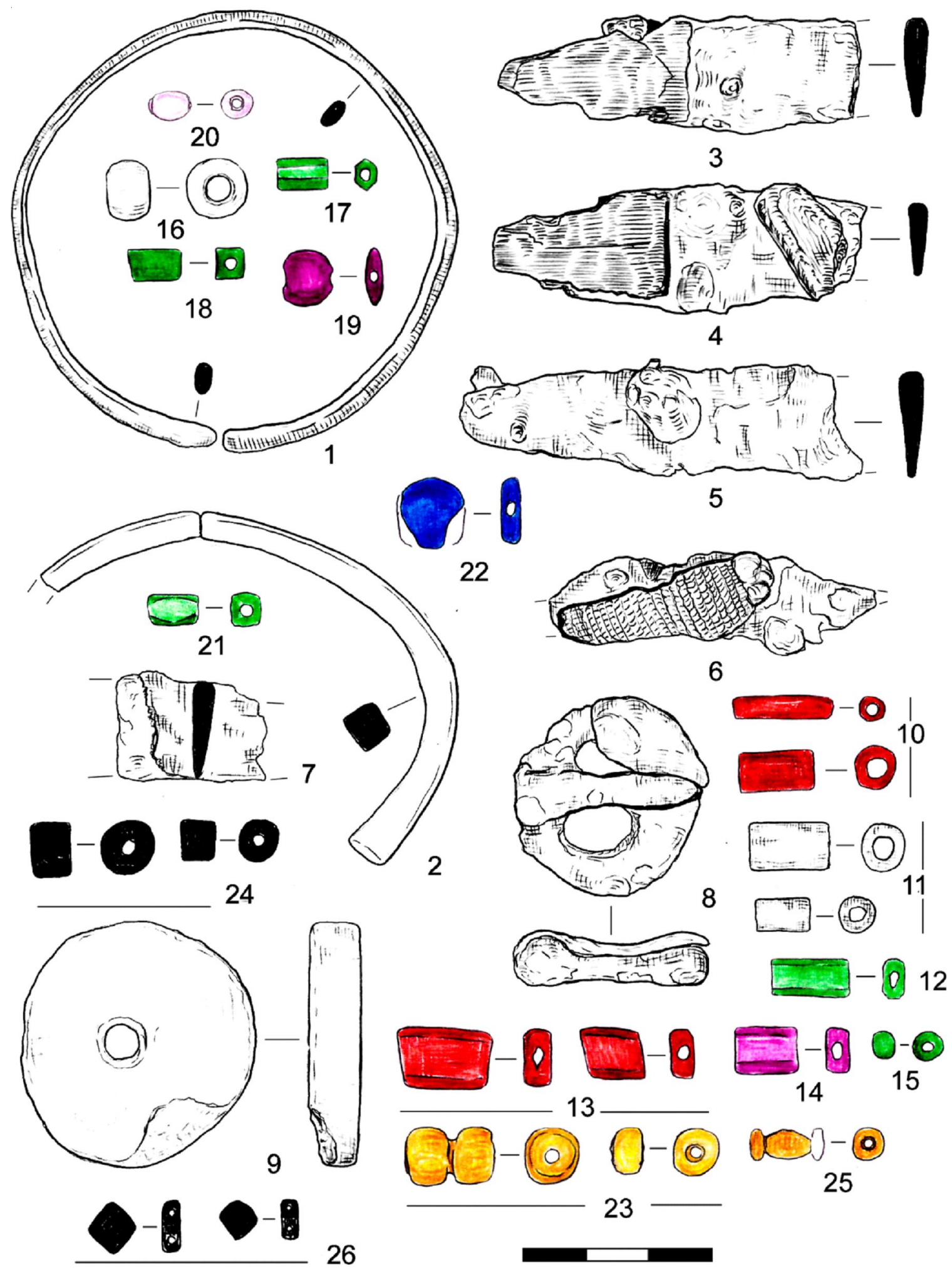

Рис. 10. Могильник Опушки, склеп № 158. Грабительский шурф (рис. С.Б. Шабанова, А.А. Стояновой): 1,2 - браслеты бронзовые; 3-7 - ножи железные; 8 - пряжка железная; 9 - пряслице керамическое; 10-26- бусы

Fig. 10. The cemetery of Opushki, burial vault no. 158. Plunderers' pit (drawing by S.B. Shabanov, A.A. Stoyanova): 1, 2 - bronze bracelets; 3-7 - iron knives; 8 - iron buckle; 9 - ceramic spindle whorl; 10-26- beads 


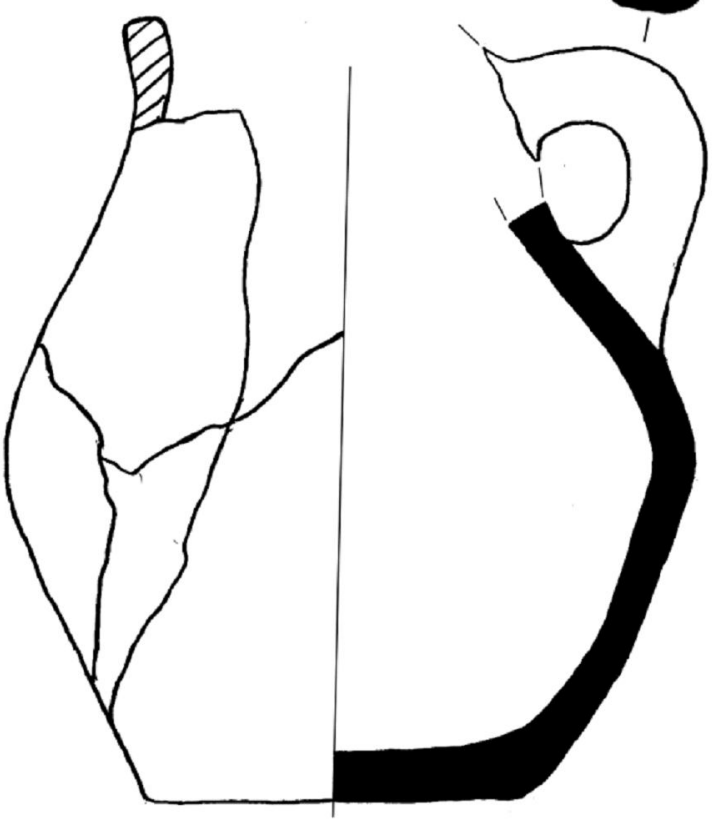

1

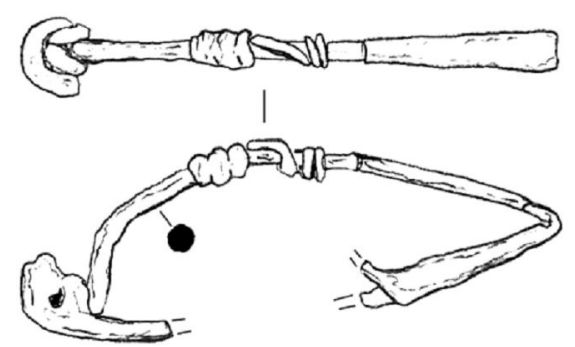

3

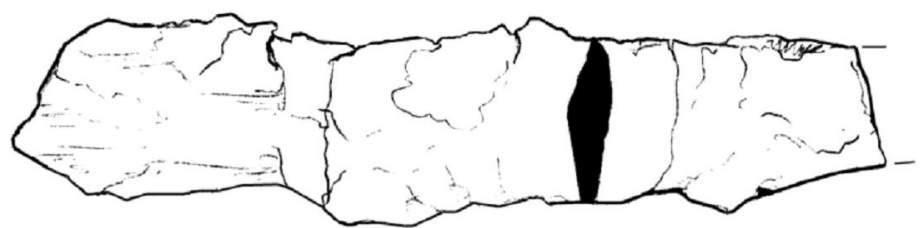

6

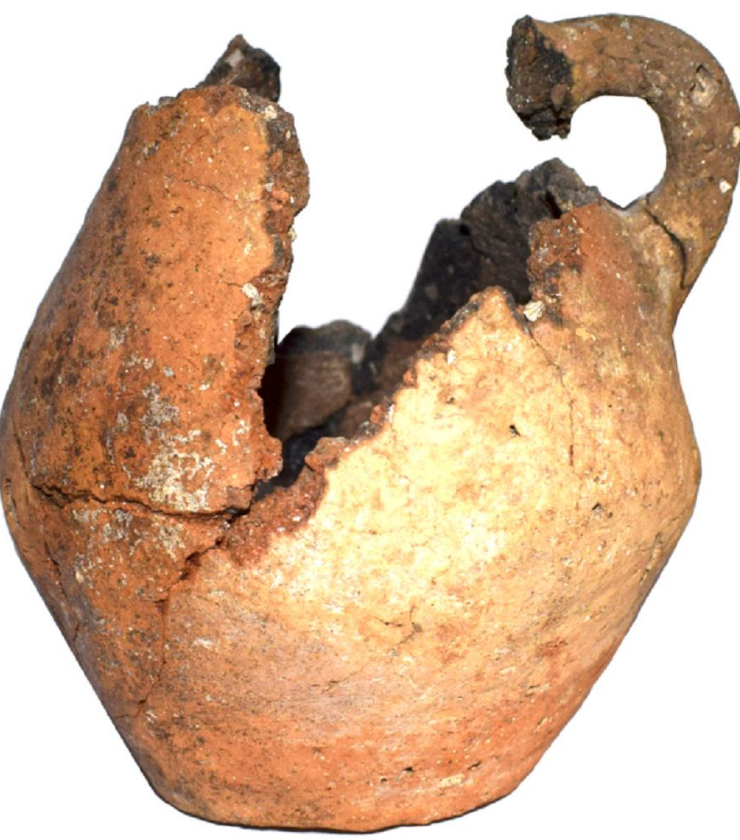

2

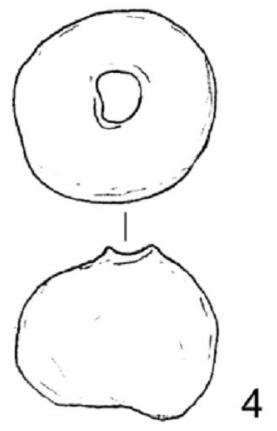

5
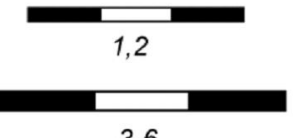

4

Рис. 11. Могильник Опушки, склеп № 158. Грабительский шурф (рис. С.Б. Шабанова):

$$
1,2 \text { - сосуд лепной. }
$$

Заполнение: 3 - фибула бронзовая, 4 - пряслице керамическое, 5 - бусина гагатовая. Входная яма: 6 - нож железный

Fig. 11. The cemetery of Opushki, burial vault no. 158. Plunderers' pit (drawing by S.B. Shabanov): 1, 2 - hand-made vessel.

Infill: 3 - bronze brooch, 4 - ceramic spindle whorl, 5 - jet bead. Entry pit: 6 - iron knife 


\section{СПИСОК ЛИТЕРАТУРЫ}

Алексеева Е. М., 1975. Античные бусы Северного Причерноморья. САИ. Вып. Г1-12. М. : Наука. 94 с.

Алексеева Е. М., 1978. Античные бусы Северного Причерноморья. САИ. Вып. Г1-12. М. : Наука. 104 с.

Алексеева Е. М., 1982. Античные бусы Северного Причерноморья. САИ. Вып. Г1-12. М. : Наука. 104 с.

Алексеева Е. М., Сорокина Н. П., 2007. Коллекция стекла античной Горгиппии (I-III вв.). М. : Интербукбизнес. $160 \mathrm{c}$.

Амброз А. К., 1966. Фибулы юга европейской части СССР. САИ. Вып. Д1-30. М. : Наука. 112 с.

Анохин В. А., 1986. Монетное дело Боспора. Киев : Наукова думка. 182 с.

Ахмедов И. Р., 2007. Инвентарь мужских погребений // Восточная Европа в середине I тыс. н.э. Археология славян и их соседей. Раннеславянский мир. Вып. 9. М. : ИА РАН. С. 137-152.

Бабенчиков В. П., 1963. Чорноріченський могильник // Археологічні пам’ятки УРСР. Т. ХІІІ. Київ : Наукова думка. С. 90-122.

Безуглов С. И., Нидзельницкая Л. Ю., 2020. Позднесарматский курган у станицы Мариинской на Дону // Крым в сарматскую эпоху (II в. до н.э. - IV в. н.э.). VI. Симферополь : Салта ЛТД. С. 215-259.

Безуглов С., Захаров А., 1989. Богатое погребение позднеримского времени близ Танаиса // Известия Ростовского областного музея краеведения. Вып. 6. Ростов н/Д : РОМК. С. 42-66.

Белоцерковская И. В., 2007. Инвентарь женских погребений // Восточная Европа в середине I тыс. н.э. Археология славян и их соседей. Раннеславянский мир. Вып. 9. М. : ИА РАН. С. 186-204.

Бертье-Делагард А. Л., 1911. Дифференты на боспорских царских монетах римского времени. М. 26 с.

Власов В. П., 1999. Лепная керамика из некрополя III - IV вв. н. э. Дружное в Крыму // Сто лет черняховской культуре. Киев : Видання Тов. археол. та антроп. С. 322-371.

Высотская Т. Н., 1980. Геммы Усть-Альминского некрополя // Вестник древней истории. № 1. С. 96-105.

Высотская Т. Н., 1994. Усть-Альминское городище и некрополь. Киев : Киевская Академия Евробизнеса. 208 с.

Гавритухин И. О., Свиридов А. Н., Язиков С. В., 2020. Могильник римского времени Фронтовое 3 в ЮгоЗападном Крыму (предварительное сообщение) // Российская археология. № 2. C. 91-110. DOI: https:// doi.org/10.31857/S086960630009075-1.

Гайдукевич В. Ф., 1959. Некрополи некоторых боспорских городов (По материалам раскопок 1930-х годов) // Некрополи боспорских городов. МИА. № 69. М. ; Л. : Наука. С. 154-238.

Журавлев Д. В., 2010. Краснолаковая керамика Юго-Западного Крыма I - III вв. н. э. (По материалам позднескифских некрополей Бельбекской долины). Симферополь : БФ «Деметра». 320 с.

Иштванович Э., Кульчар В., Стоянова А. А., 2020. Бусы в костюме населения сарматского времени Крыма и Альфёльда // Крым в сарматскую эпоху (II в. до н.э. - IV в. н.э.). VI. Симферополь : Салта ЛТД. С. $10-43$.

Краснодубец Е. М., 2019. Перстень с астральной символикой из раскопок К. К. Косцюшко-Валюжинича в Херсонесе Таврическом // Исторические, культурные, межнациональные, религиозные и политические связи Крыма со Средиземноморским регионом и странами Востока : материалы конф. Т. 1. М. : Пробел-2000. С. 149-153.

Кропотов В. В., 2010. Фибулы сарматской эпохи. Киев : ИД «АДЕФ-Украина». 384 с.

Лысенко А. В., Масякин В. В., Мордвинцева В. И., 2015. Могила № 1 некрополя римского времени Лучистое-2 (Южный Крым) // История и археология Крыма. Т. 2. Симферополь. С. 295-333.

Максимова М. И., 1957. Боспорская камнерезная мастерская // Советская археология. № 4. С. 75-82.

Малашев В. Ю., 2000. Периодизация ременных гарнитур позднесарматского времени // Сарматы и их соседи на Дону. Материалы и исследования по археологии Дона. Вып. І. Ростов н/Д : Терра : Гефест. C. $194-132$.

Мастыкова А. В., Казанский М. М., Сапрыкина И. А., 2016. Пашковский могильник № 1. Т. 2 : Исследование материалов Пашковского могильника № 1. М. : ИА РАН ; СПб. : Нестор-История. 372 с.

Мошкова М. Г., Малашев В. Ю., 1999. Типология и хронология сарматских погребальных катакомбных сооружений // Археология Волго-Уральского региона в эпоху раннего железного века и средневековья. Волгоград : Изд-во ВолГУ. С. 172-212. 
Мульд С. А., 2011. Склеп с двумя погребальными камерами из могильника Левадки // Материалы по археологии, истории и этнографии Таврии. Вып. XVII. С. 94-115.

Мульд С. А., 2016. Погребальные сооружения могильника Нейзац // Крым в сарматскую эпоху (II в. до н.э. IV в. н.э.). II. Симферополь : Наследие тысячелетий. С. 37-75.

Мульд С. А., Масякин В. В., 2003. Позднескифский склеп № 20 могильника у с. Левадки // Материалы по археологии, истории и этнографии Таврии. Вып. Х. С. 5-31.

Мыц В. Л., Лысенко А. В., Щукин М. Б., Шаров О. В., 2006. Чатыр-Даг-некрополь римской эпохи в Крыму. СПб. : Нестор-История. 208 с.

Неверов О. Я., 1979. Гностические геммы, перстни и амулеты юга СССР // Вестник древней истории. № 1 (147). C. 95-103.

Пуздровский А. Е., 2007. Крымская Скифия II в. до н. э. - III в. н. э. Погребальные памятники. Симферополь : Бизнес-Информ. 480 с.

Пуздровский А. Е., Зайцев Ю. П., Неневоля И. И., 2001. Новые памятники III-IV вв. н. э. в Эго-Западном Крыму// Материалы по археологии, истории и этнографии Таврии. Вып. VIII. C. 32-50.

Пуздровский А. Е., 2014. Два комплекса раннеримского времени из Усть-Альминского некрополя // История и археология Крыма. Вып. І. Симферополь : Бизнес-Информ. С. 170-182.

Пуздровский А. Е., Труфанов А. А., 2015. Два склепа в центральной части Усть-Альминского некрополя // История и археология Крыма. Вып. ІІ. Симферополь : Бизнес-Информ. С. 200-231.

Пуздровский А. Е., Труфанов А. А., 2016. Полевые исследования Усть-Альминского некрополя в 2008-2014 гг. Симферополь : ИП Бровко А. А. 308 с.

Пуздровский А. Е., Труфанов А. А., 2017а. Полевые исследования Усть-Альминского некрополя в 20042007 гг. Симферополь : ИП Бровко А. А. 372 c.

Пуздровский А. Е., Труфанов А. А., 2017б. Полевые исследования Усть-Альминского некрополя в 20002003 гг. Симферополь : ИП Зуева Т. В. 300 с.

Свиридов А. Н., Язиков С. В., 2019. Погребальные обряды могильника римского времени Фронтовое 3 в ЮгоЗападном Крыму // Краткие сообщения Института археологии. Вып. 255. C. 185-201. DOI: https:/doi.org/ 10.25681/IARAS.0130-2620.255.185-201.

Ставицкий В. В., 2015. Тордированные гривны из древнемордовских могильников І тысячелетия н. э. // История и археология. № 2. URL: http://history.snauka.ru/2015/02/1448 (дата обращения: 13.02.2021).

Стоянова А. А., 2004. Бусы и подвески из могильника Нейзац (по материалам раскопок 1996-2001 гг.) // Боспорские исследования. Вып. V. С. 263-320.

Стоянова А. А., 2011а. Гривны из памятников Крыма сарматского времени // Материалы по археологии, истории и этнографии Таврии. Вып. XVII. С. 116-140.

Стоянова А. А., 2011б. Аксессуары женского костюма II - первой половины III в. н. э. из могильника Нейзац // Исследования могильника Нейзац. Симферополь : Доля. С. 115-152.

Стоянова А. А., 2012. Детские погребения из могильника Опушки (по результатам раскопок 2003 - 2009 гг.). Симферополь : Доля. 100 с.

Стоянова А. А., 2016. Подвески из могильника Нейзац // Крым в сарматскую эпоху (II в. до н.э. - IV в. н.э.). II. Симферополь : Наследие тысячелетий. С. 122-165.

Стржелецкий С. Ф., Высотская Т. Н., Рыжова Л. А., Жесткова Г. И., 2003-2004. Население округи Херсонеса в первой половине І тысячелетия новой эры (по материалам некрополя «Совхоз 10») // Stratum plus. № 4. C. 27-277.

Суханов Е. В., 2020. Лепная керамика могильника римского времени Фронтовое 3 (предварительная публикация) // Материалы по археологии, истории и этнографии Таврии. Вып. XXV. C. 66-89.

Сымонович Э. А., 1983. Население столицы позднескифского царства (по материалам Восточного некрополя Неаполя скифского). Киев : Наукова думка. 173 с.

Труфанов А. А., 1997. Типология краснолаковых тарелок с вертикальным бортиком (по материалам могильников юго-западного и центрального Крыма) // Бахчисарайский историко-археологический сборник. Вып. І. Симферополь : Таврия. С. 181-192.

Труфанов А. А., 2004. Подбойные могилы ІІІ в. н. э. некрополя у с. Курское (по материалам раскопок 2001 г.) // Сугдейский сборник. Вып. І. Киев ; Судак : Академпериодика. С. 495-521. 
Труфанов А. А., 2019. Региональные отличия комплекса бронзовых украшений конца II - середины III в. н. э. из погребений центральной части предгорного и горного Крыма // XX Боспорские чтения. Боспор Киммерийский и варварский мир в период античности и средневековья. Основные итоги и перспективы исследований. Симферополь ; Керчь : [б. и.]. С. 573-580.

Филиппенко А. А., Тюрин М. И., Ушаков С. В., 2016. О могильнике ВИР (Бельбек III) в Юго-Западном Крыму: новые данные // Stratum plus. № 4. С. 139-151.

Хайрединова Э. А., 1995. Бусы из могильника Дружное // Проблемы археологии древнего и средневекового Крыма. Симферополь : Таврия. С. 59-87.

Храпунов И. Н., 2002. Могильник Дружное (III - IV вв. н. э.). Lublin: Wydawnictwo Uniwersytetu Marii CurieSkiodowskiej. 314 c.

Храпунов И. Н., 2006. Погребения детей в могильнике Нейзац // Материалы по археологии, истории и этнографии Таврии. Вып. ХІІ, ч. 1. С. 161-250.

Храпунов И. Н., 2008. Наконечники ремней из могильника Нейзац // Материалы по археологии, истории и этнографии Таврии. Вып. XIV. С. 61-79.

Храпунов И. Н., 2011а. Некоторые итоги исследований могильника Нейзац // Исследования могильника Нейзац. Симферополь : Доля. С. 13-113.

Храпунов И. Н., 2011б. Склеп с погребениями III - IV вв. н. э. из могильника Нейзац. Симферополь : Доля. 72 с.

Храпунов И. Н., 2018а. Склепы с короткими дромосами в Крыму и на Северном Кавказе // Крым в сарматскую эпоху (II в. до н.э. - IV в. н.э.). IV. Симферополь : ИП Бровко А. А. С. 133-145.

Храпунов И. Н., 2018б. Склеп с вещами в догуннском полихромном стиле из могильника Опушки // Крым в сарматскую эпоху (II в. до н. э. - IV в. н. э.). III. Симферополь : ИП Бровко А. А. С. 137-169.

Храпунов И. Н., 2020. Склеп с монетами III в. н.э. из могильника Опушки // Нижневолжский археологический вестник. Т. 19, № 2. С. 247-278. DOI: https://doi.org/10.15688/nav.jvolsu.2020.2.13.

Храпунов И. Н., Мульд С. А., 2004. Склепы с погребениями III в. н. э. из могильника Нейзац // Боспорские исследования. Вып. VII. С. 299-326.

Храпунов И. Н., Мульд С. А., Стоянова А. А., 2009. Позднескифский склеп из могильника Опушки. Симферополь : Доля. $96 \mathrm{c}$.

Храпунов И. Н., Стоянова А. А., 2020. Каменный склеп Опушкинского могильника // Крым в сарматскую эпоху (II в. до н.э. - IV в. н.э.). VI. Симферополь : Салта ЛТД. С. 66-112.

Храпунов И. Н., Стоянова А. А., Мульд С. А., 2001. Позднескифский могильник у с. Левадки // Бахчисарайский историко-археологический сборник. Вып. 2. Симферополь : Таврия-плюс. С. 105-168.

Шабанов С. Б., 2020. Новые находки стеклянных сосудов позднеримского времени в крымских предгорьях // XXI Боспорские чтения. Боспор Киммерийский и варварский мир в период античности и средневековья. Объекты искусства в археологическом контексте. Симферополь, Керчь. С. 392-397.

Шаров О. В., 2007. Керамический комплекс некрополя Чатыр-Даг : Хронология комплексов с римскими импортами. Краснолаковая керамика. СПб. : Нестор-История. 208 с.

Cravinho G., 2017. Roman Engraved Gems in the National Archaeological Museum in Lisbon // Studies in Ancient art and civilization. Vol. 21. P. 173-245.

Khrapunov I., Kazanski M., 2016. A Grave from the Hunnic Period in the Cemetery of Neizats (Central Crimea) // Archäologische Korrespondenzblatt. Vol. 46. S. 363-378.

MattinglyH., Sydenham E. A., 1936. The Roman Imperial Coinage. Vol. IV. Pt. I. Pertinax to Geta. L. : Spink \& Son. 406 p.

Spier J., 1992. Ancient Gems and Finger Rings: Catalogue of the Collections of the J. Paul Getty Museum. MalibuCalifornia : J. Paul Getty Museum. 200 p.

\section{REFERENCES}

Alekseeva E.M., 1975. Antichnye busy Severnogo Prichernomor'ya [Ancient Beads in the Northern Black Sea Area]. Svod arkheologicheskikh istochnikov, vol. Г1-12. Moscow, Nauka Publ. 94 p.

Alekseeva E.M., 1978. Antichnye busy Severnogo Prichernomor'ya [Ancient Beads in the Northern Black Sea Area]. Svod arkheologicheskikh istochnikov, vol. Г1-12. Moscow, Nauka Publ. 104 p. 
Alekseeva E.M., 1982. Antichnye busy Severnogo Prichernomor'ya [Ancient Beads in the Northern Black Sea Area]. Svod arkheologicheskikh istochnikov, vol. Г1-12. Moscow, Nauka Publ. 104 p.

Alekseeva E.M., Sorokina N.P., 2007. Kollektsiya stekla antichnoy Gorgippii (I-IIIvv.) [A Collection of the Glassware of Ancient Gorgippia (First to Third Century AD)]. Moscow, Interbook Publ. 160 p.

Ambroz A.K., 1966. Fibuly iuga ievropeyskoy chasti SSSR. II v. do n. e. - IV v. n. e. [The Brooches on the South of the European Part of the USSR, Second Century BC to Fourth Century AD]. Svod arkheologicheskikh istochnikov, vol. Д1-30. Moscow, Nauka Publ. 112 p.

Anokhin V.A., 1986. Monetnoe delo Bospora [The Coinage of Bosporus]. Kiev, Naukova dumka Publ. 182 p.

Akhmedov I.P., 2007. Inventar' muzhskikh pogrebenii [Grave Goods in Male Burials]. Vostochnaya Evropa v seredine I tys. n.e. [Eastern Europe in the middle of the $1^{\text {st }}$ millennium AD]. Arkheologiia slavian i ikh sosedey. Iss. 9. Moscow, IA RAS, pp. 137-152.

Babebchikov V.P., 1963. Chornorichens'kyy mohyl'nyk [Chernorech'e Cemetery]. Arkheolohychni pam 'iatky URSR [Archaeological Sites in the Ukrainian SSR], vol. XIII. Kiev, Naukova Dumka Publ., pp. 90-122.

Bezuglov S.I., Nidzel'nitskaia L.Yu., 2020. Pozdnesarmatskiy kurgan u stanitsy Mariinskoy na Donu [A Late Sarmatian Barrow at Mariinskaia Cossack Village in the Don Area]. Krym v sarmatskuyu epokhu (II v. do n. e. -IV v. n. e.) [The Crimea in the Age of the Sarmatians (200 BC-AD 400)], vol. VI. Simferopol, Salta Publ., pp. 215-259.

Bezuglov S., Zakharov A., 1989. Bogatoe pogrebenie pozdnerimskogo vremeni bliz Tanaisa [A Rich Grave from the Late Roman Period in Vicinity of Tanais]. Izvestiya Rostovskogo oblastnogo muzeya kraevedeniya [Proceedings of the Rostov Regional Museum], iss. 6. Rostov-na-Donu, Rostov Regional Museum of Local Lore, pp. 42-66.

Belotserkovskaya I.V., 2007. Inventar' zhenskikh pogrebenii [Grave Goods from Female Burials]. Vostochnaya Evropa $v$ seredine Itys. n.e. [Eastern Europe in the middle of the $1^{\text {st }}$ millennium AD]. Arkheologiia slavian i ikh sosedey. Iss. 9. Moscow, IA RAS, pp. 186-204.

Bert'e-Delagard A.L., 1911. Differenty na bosporskikh tsarskikh monetakh rimskogo vremeni [Countermarks on the Coins of Bosporan Kings from the Roman Period]. Moscow. $26 \mathrm{p}$.

Vlasov V.P., 1999. Lepnaya keramika iz nekropolya III-IV vv. n. e. Druzhnoe v Krymu [Hand-made Pottery from the Third-to-Fourth-Century AD Cemetery of Druzhnoe in the Crimea]. Sto let chernyakhovskoy kul ture [The Centenary of the Chernyakhov Culture]. Kiev, Vidannya tov. arkheol. ta. antrop., pp. 322-371.

Vysotskaya T.N., 1980. Gemmy Ust'-Al'minskogo nekropolia [Gems from the Ust-Alminsky Necropolis]. Vestnik drevney istorii [Journal of Ancient History], no. 1, pp. 96-105.

Vysotskaya T.N., 1994. Ust'-Al'minskoe gorodishche i nekropol' [The Settlement and Cemetery of Ust'-Al'ma]. Kiev, Akademiya Evrobiznesa Publ. 208 p.

Gavritukhin I.O., Sviridov A.N., Yazikov S.V., 2020. Mogil'nik rimskogo vremeni Frontovoe 3 v Yugo-Zapadnom Krymu (predvaritel'noe soobshchenie) [The Roman Period Cemetery of Frontovoe 3 in the South-Western Crimea (a Preliminary Publication)]. Rossiyskaya arkheologiya [Russian Archaeology], no. 2, pp. 91-110. DOI: https://doi.org/10.31857/S086960630009075-1.

Gaydukevich V.F., 1959. Nekropoli nekotorykh bosporskikh gorodov (po materialam raskopok 1930-kh godov) [The Cemeteries of Some Bosporan Towns (According to the 1930s Excavations)]. Nekropoli bosporskikh gorodov [The Cemeteries of Bosporan Towns]. Materialy i issledovaniya po arkheologii SSSR, no. 69. Moscow, Leningrad, Nauka Publ., pp. 154-238.

Zhuravlev D.V., 2010. Krasnolakovaya keramika Yugo-Zapadnogo Kryma I-III vv. n. e.: (po materialam pozdneskifskikh nekropoley Bel'bekskoy doliny) [The Red Slip Ware in the South-Western Crimea from the First to Third Century AD (According to the Finds from the Late Scythian Cemeteries in the Bel'bek River Valley)]. Simferopol, Non-profitable Foundation «Demetra». 320 p.

Istvánovits E., Kulcsár V., Stoyanova A.A., 2020. Busy v costume naseleniia sarmatskogo vremeni Kryma i Al'fel'da [Beads in the costume of the Sarmatian Age population in the Crimea and Great Hungarian Plain]. Krym $v$ sarmatskuiu epokhu (II v. do n. e. -IV v. n. e.) [The Crimea in the Age of the Sarmatians (200 BC-AD 400)], vol. VI. Simferopol, Salta Publ., pp. 10-43.

Krasnodubets E.M., 2019. Persten's astral'noy simvolikoy iz raskopok K. K. Kostsyushko-Valyuzhinicha v Khersonese Tavricheskom [A Finger-ring Featuring Astral Symbols Excavated by K. K. KostsyushkoValyuzhinich in Tauric Chersonese]. Istoricheskie, kul 'turnye, mezhnatsional'nye, religioznye i politicheskie sviazi Kryma so Sredizemnomorskim regionom i stranami Vostoka: materialy konferentsii [Historical, Cultural, 
Interethnic, Religious, and Political Connections of the Crimea and the Mediterranean and the Countries of Orient: Conference Proceedings], vol. 1. Moscow, Probel-2000 Publ., pp. 149-153.

Kropotov V.V., 2010. Fibuly sarmatskoy epokhi [Brooches from the Sarmatian Period]. Kiev, ADEF-Ukraine Publ., $384 \mathrm{p}$.

Lysenko A.V., Masyakin V.V., Mordvintseva V.I., 2015. Mogila no. 1 nekropolya rimskogo vremeni Luchistoe-2 (Yuzhnyy Krym) [Grave 1 in the Cemetery of Luchistoe-2 from the Roman Period (Southern Crimea)]. Isrotiya i arkheologiya Kryma [History \& Archaeology of Crimea], vol. 2. Simferopol, pp. 295-333.

Maksimova M.I., 1957. Bosporskaia kamnereznaia masterskaia [A Bosporan Stone-Carving Workshop]. Sovetskaya arkheologiya [Soviet Archaeology], no. 4, pp. 75-82.

Malashev V.Yu., 2000. Periodizatsiya remennykh garnitur pozdnesarmatskogo vremeni [A Periodization of Belt Sets from the Late Sarmatian Period]. Sarmaty i ikh sosedi na Donu [The Sarmatians and Their Neighbours on the Don]. Rostov-on-Don, Terra Publ., Gefest Publ., pp. 194-232.

Mastykova A.V., Kazanski M.M., Saprykina I.A., 2016. Pashkovskiy mogil'nik no. 1. Vol. 2: Issledovanie materialov Pashkovskogo mogil'nika no. 1 [Pashkovskaia 1 Cemetery. Vol. 2: A Study of the Materials of the Pashkovskaia 1 Cemetery]. Moscow; Saint Petersburg, Nestor-Istoriya Publ. 372 p.

Moshkova M.G., Malashev V.Yu., 1999. Tipologiya i khronologiya sarmatskikh pogrebalnykh katakombnykh sooruzheniy [A Typology and Chronology of Sarmatian Burial Catacomb Structures]. Arkheologiya VolgoUral'skogo regiona v epokhu rannego zheleznogo veka i srednevekov'ya [Archaeology of the Volga-Ural Area in the Early Iron Age and Middle Ages]. Volgograd, VolSU, pp. 172-212.

Mul'd S.A., 2011. Sklep s dvumya pogrebal'nymi kamerami iz mogil'nika Levadki [A Vault with two Burial Chambers from the Cemetery of Levadki]. Materialy po arkheologii, istorii i etnografii Tavrii [Materials in Archaeology, History and Ethnography of Tauria], iss. XVII, pp. 94-115.

Mul'd S.A., 2016. Pogrebal'nye sooruzheniya mogil'nika Neizats [Burial Structures in the Cemetery of Neizats]. Krym v sarmatskuyu epokhu. II. 20 let issledovaniy mogil'nika Neizats [The Crimea in the Age of the Sarmatians (200 BC AD 400). Vol. II: 20 Years of Researches at the Cemetery of Neizats]. Simferopol, Nasledie tysiacheletiy Publ., pp. 35-75.

Mul'd S.A., Masyakin V.V., 2003. Pozdneskifskiy sklep no. 20 mogil'nika u s. Levadki [Late Scythian Vault no. 20 in the Cemetery near the Village of Levadki]. Materialy po arkheologii, istorii i etnografii Tavrii [Materials in Archaeology, History and Ethnography of Tauria], iss. X, pp. 5-31.

Myts V.L., Lysenko A.V., Shchukin M.B., Sharov O.V., 2006. Chatyr-Dag-nekropol'rimskoy epokhi v Krymu [Chatyr-Dag: a Cemetery from the Roman Period in the Crimea]. Saint Petersburg, Nestor-Istoriya Publ. 208 p.

Neverov O.Ya., 1979. Gnosticheskie gemmy, perstni i amulety yuga SSSR [Gnostic Gem and Amulets from Southern USSR]. Vestnik drevney istorii [Journal of Ancient History], no. 1 (147), pp. 95-103.

Puzdrovskiy A.E., 2007. Krymskaya Skifiya II v. do n. e. - III v. n. e. Pogrebal'nye pamiatniki [Crimean Scythia from the Second Century BC to the Third Century AD: Funeral Monuments]. Simferopol, Biznes-Inform Publ., 480 p.

Puzdrovskiy A.E., Zaytsev Yu.P., Nenevolya I.I., 2001. Novye pamiatniki III-IV vv. n. e. v Yugo-Zapadnom Krymu [New Sites from the Third to Fourth Century AD in the South-Western Crimea]. Materialy po arkheologii, istorii i etnografii Tavrii [Materials in Archaeology, History and Ethnography of Tauria], iss. VIII, pp. 32-50.

Puzdrovskiy A.E., 2014. Dva kompleksa rannerimskogo vremeni iz Ust'-Al'minskogo nekropolya [Two Complexes from the Early Roman Period in Ust'-Al'ma Cemetery]. Istoriya i arkheologiya Kryma [History \& Archaeology of Crimea], vol. I. Simferopol, Biznes-Inform Publ., pp. 170-182.

Puzdrovskiy A.E., Trufanov A.A., 2015. Dva sklepa v tsentralnoy chasti Ust'-Al'minskogo nekropolia [Two Burial Vaults in the Central Area of Ust'-Al'ma Cemetery]. Istoriya i arkheologiya Kryma [History \& Archaeology of Crimea], vol. II. Simferopol, pp. 200-231.

Puzdrovskiy A.E., Trufanov A.A., 2016. Polevye issledovaniya Ust'-Al'minskogo nekropolya v 2008-2014 gg. [Field Researches at Ust'-Al'ma Cemetery in 2008-2014]. Simferopol, Brovko A. Publ., 308 p.

Puzdrovskiy A.E., Trufanov A.A., 2017a. Polevye issledovaniya Ust'-Al'minskogo nekropolia v 2004-2007 gg. [Field Researches at Ust'-Al'ma Cemetery in 2004-2007]. Simferopol, IP Brovko A. A. Publ., 372 p.

Puzdrovskiy A.E., Trufanov A.A., 20176. Polevye issledovaniya Ust'-Al'minskogo nekropolya v 2000-2003 gg. [Field Researches at Ust'-Al'ma Cemetery in 2000-2003]. Simferopol, IP Zueva T. V. Publ., 300 p.

Sviridov A.N., Yazikov S.V., 2019. Pogrebal'nye obryady mogil'nika rimskogo vremeni Frontovoe 3 v Yugo-Zapadnom Krymu [Burial Rites at the Frontovoye-3 Cemetery in the Southwest Crimea]. Kratkie soobscheniya Instituta 
arkheologii [Brief Communications of the Institute of Archaeology], vol. 255, pp. 185-201. DOI: https:// doi.org/10.25681/IARAS.0130-2620.255.185-201.

Stavitskiy V.V., 2015. Tordirovannye grivny iz drevnemordovsikh mogil'nikov I tysyacheletiya n. e. [Torque-like Neck-rings from Ancient Mordva Cemeteries from the First Millennium AD]. Istoriya i arkheologiya [History and Archaeology], no. 2. URL: http://history.snauka.ru/2015/02/1448 (accessed 13 February 2021).

Stoyanova A.A., 2004. Busy i podveski iz mogil'nika Neizats (po materialam raskopok 1996-2001 gg.) [Beads and Pendants from the Cemetery of Neizats (According to the 1996-2001 Excavation Materials]. Bosporskie issledovaniya [Bosporos Studies], iss. V, pp. 263-320.

Stoyanova A.A., 2011a. Grivny iz pamiatnikov Kryma sarmatskogo vremeni [Neck-Rings in the Crimean Sites from the Sarmatian Period]. Materialy po arkheologii, istorii i etnografii Tavrii [Materials in Archaeology, History and Ethnography of Tauria], iss. XVII, pp. 116-140.

Stoyanova A.A., 20116. Aksessuary zhenskogo kostyuma II - pervoy poloviny III v. n.e. iz mogil'nika Neizats [The Second and the First Half of the third Century AD Female Costume Accessories from the Cemetery of Neizats]. Issledovaniia mogil'nika Neizats [Exploring the Cemetery of Neizats]. Simferopol, Dolya Publ., pp. 115-152.

Stoyanova A.A., 2012. Detskie pogrebeniya iz mogil'nika Opushki (po rezul'tatam raskopok 2003-2009 gg.) [Children's Burials in the Cemetery of Opushki (According to 2003-2009 Excavations)]. Simferopol, Dolya Publ. $100 \mathrm{p}$.

Stoyanova A.A., 2016. Podveski iz mogil'nika Neizats [Pendants from the Cemetery of Neizats]. Krym v sarmatskuyu epokhu (II v. do n. e. $-I V$ v.n. e.). II. 20 let issledovanii mogil'nika Neizats [The Crimea in the Age of the Sarmatians (200 BC AD 400). Vol. II: 20 Years of Researches at the Cemetery of Neizats]. Simferopol, Nasledie tysiacheletiy Publ., pp. 122-165.

Strzheletskiy S.F., Vysotskaya T.N., Ryzhova L.A., Zhestkova G.I., 2003-2004. Naselenie okrugi Khersonesa v pervoy polovine I tysiacheletiya novoy ery (po materialam nekropolya "Sovkhoz № 10” [The Population in the Neighborhood of Chersonesos Tauricus in the First Half of $1^{\text {st }}$ Millennium A.D. (by materials of the necropolis “Sovkhoz No. 10")]. Stratum plus, no. 4, pp. 27-277.

Sukhanov Ye.V., 2020. Lepnaya keramika mogil'nika rimskogo vremeni Frontovoe 3 (predvaritel'naia publikatsiia) [Hand-made pottery in the Roman period cemetery of Frontovoe 3 (a preliminary publication)]. Materialy po arkheologii, istorii i etnografii Tavrii [Materials in Archaeology, History and Ethnography of Tauria], vol. XXV, pp. 66-89.

Symonovich E.A., 1983. Naselenie stolitsy pozdneskifskogo tsarstva (po materialam Vostochnogo nekropolia Neapolya Skifskogo) [The Population of the Capital of the Late Scythian Kingdom (According to the Materials from the Eastern Cemetery of Scythian Neapolis)]. Kiev, Naukova dumka Publ. 173 p.

Trufanov A.A., 1997. Tipologiya krasnolakovykh tarelok s vertikal'nym bortikom (po materialam mogil'nikov yugozapadnogo Kryma) [A Typology of the Red-slip Plates with Vertical Border (According to the Materials from the South-Western Crimea)]. Bakhchisarayskiy istoriko-arkheologicheskiy sbornik [Bakhchisaray Historical and Archaeological Proceedings], iss. I. Simferopol, Tavriya Publ., pp. 181-192.

Trufanov A.A., 2004. Podboinye mogily III v. n.e. nekropolya u s. Kurskoe (po materialam reskopok 2001 g.) [The Third-Century AD Undercut Graves in the Cemetery of Kurskoe (according to 2001 Excavation Materials)]. Sugdeyskiy sbornik [Sougdaia Proceedings], iss. I. Kiev, Sudak, Akademperiodika Publ., pp. 495-521.

Trufanov A.A., 2019. Regional'nye otlichiya kompleksa bronzovykh ukrasheniy kontsa II - serediny III v. n.e. iz pogrebeniy tsentral'noy chasti predgornogo i gornogo Kryma [Regional Differences of the Bronze Ornaments Complex from the Late Second to the Mid-Third Century AD from the Burials in the Central Area of the Foothill and Mountainous Crimea]. XX Bosporskie chteniya. Bospor Kimmeriyskiy i varvarskiy mir v period antichnosti i srednevekov'ya. Osnovnye itogi i perspektivy issledovaniy [XX Bosporan Readings. Cimmerian Bosporus and the World of Barbarians in Antiquity and Middle Age. Main Result and Prospects of Research]. Simferopol, Kerch, pp. 573-580.

Fillipenko A.A., Tiurin M.I., Ushakov S.V., 2016. O mogil'nike VIR (Bel'bek III) v Yugo-Zapadnom Krymu: novye dannye [In the Necropolis VIR (Belbek III) in South-Western Crimea: the New Data]. Stratum plus, no. 4, pp. 139-151.

Khayredinova E.A., 1995. Busy iz mogil'nika Druzhnoe [The Beads from the Cemetery of Druzhnoe]. Problemy arkheologii drevnego i srednevekovogo Kryma [The Aspects of Archaeology of the Ancient and Mediaeval Crimea]. Simferopol, Tavriya Publ., pp. 59-87. 
Khrapunov I.N., 2002. Mogil'nik Druzhnoe (III-IVvv. n. e.) [The Cemetery of Druzhnoe(Third and Fourth Centuries AD)]. Lublin, Wydawnictvo Universitetu Marii Curie-Skladowskiej. 314 p.

Khrapunov I.N., 2006. Pogrebeniya detey v mogil'nike Neizats [Children's Burials in the Cemetery of Neizats]. Materialy po arkheologii, istorii i etnografii Tavrii [Materials in Archaeology, History and Ethnography of Tauria], iss. XII, pt. 2, pp. 161-250.

Khrapunov I.N., 2008. Nakonechniki remney iz mogil’nika Neizats [Strap-Ends from the Cemetery of Neizats]. Materialy po arkheologii, istorii i etnografii Tavrii [Materials in Archaeology, History and Ethnography of Tauria], iss. XIV, pp. 61-79.

Khrapunov I.N., 2011a. Nekotorye itogi issledovaniy mogil'nika Neizats [Some Results of the Researches of the Cemetery of Neizats]. Issledovaniya mogil'nika Neizats [Exploring the Cemetery of Neizats]. Simferopol, Dolya Publ., pp. 13-113.

Khrapunov I.N., 20116. Sklep s pogrebeniyami III-IVvv. n. e. iz mogil'nika Neizats [A Vault with the Third and Fourth Century AD Burials in the Cemetery of Neizats]. Simferopol, Dolya Publ. 72 p.

Khrapunov I.N., 2018a. Sklepy s korotkimi dromosami v Krymu i na Severnom Kavkaze [Burial Short-corridor Vaults in the Crimea and in the North Caucasus]. Krym v sarmatskuyu epokhu (II v. do n. e. - IV v. n. e.) [The Crimea in the Age of the Sarmatians (200 BC-AD 400)], vol. IV. Simferopol, IP Brovko A.A. Publ., pp. 133-145.

Khrapunov I.N., 20186. Sklep s veshchami v dogunnskom polikhromnom stile iz mogil'nika Opushki [A Burial Vault with Artefacts in the Pre-Hunnic Polychrome Style in Opushki Cemetery]. Krym v sarmatskuyu epokhu (II v. do n. e. IVv. n. e.) [The Crimea in the Age of the Sarmatians (200 BC AD 400)], vol. III. Simferopol, IP Brovko A. A. Publ., pp. 137-169.

Khrapunov I.N., 2020. Sklep s monetami III v. n.e. iz mogil'nika Opushki [A Crypt with Third-Century Coins in the Cemetery of Opushki]. Nizhnevolzhskiy Arkheologicheskiy Vestnik [The Lower Volga Archaeological Bulletin], vol. 19, no. 2, pp. 247-278. DOI: https://doi.org/10.15688/nav.jvolsu.2020.2.13

Khrapunov I.N., Mul'd S.A., 2004. Sklepy s pogrebeniyami III v. n. e. iz mogil'nika Neizats [The Vaults with the Third-Century AD Burials in the Cemetery of Neizats]. Bosporskie issledovaniya [Bosporos Studies], vol. VII, pp. 299-326.

Khrapunov I.N., Mul'd S.A., Stoyanova A.A., 2009. Pozdneskifskiy sklep iz mogil'nika Opushki [A Late Scythian Vault from the Cemetery of Opushki]. Simferopol, Dolya Publ. 96 p.

Khrapunov I.N., Stoyanova A.A., 2020. Kamennyy sklep Opushkinskogo mogil'nika [A Stone Burial Vault at the Cemetery of Opushki]. Krym v sarmatskuyu epokhu (II v. do n. e. $-I V v$. n. e.) [The Crimea in the Age of the Sarmatians (200 BC AD 400)], iss. VI. Simferopol, Salta Publ., pp. 66-112.

Khrapunov I.N., Stoyanova A.A., Mul'd S.A., 2001. Pozdneskifskiy mogilnik y sela Levadki [Late Scythian Cemetery near Levadki village]. Bakhchisarayskiy istoriko-arkheologicheskiy sbornik [Bakhchisaray Historical and Archaeological Collected], iss. 2. Simferopol, Tavriya-plus Publ., pp. 105-168.

Shabanov S.B., 2020. Novye nakhodki stekliannykh sosudov pozdnerimskogo vremeni v krymskikh predgor'iakh [New Finds of Glass Vessels from the Late Roman Period in the Crimean Foothills]. XXI Bosporskie chteniya. Bospor Kimmeriyskiy $i$ varvarskiy mir v period antichnosti i srednevekov'ya. Ob'ekty iskusstva v arkheologicheskom kontekste [Bosporan Readings. Cimmerian Bosporus and the World of Barbarians in Antiquity and Middle Age. Objects of Art in Archaeological Context]. Simferopol, Kerch, pp. 392-397.

Sharov O.V., 2007. Keramicheskiy kompleks nekropolya Chatyr-Dag: khronologiya kompleksov s rimskimi importami [The Pottery Complex of the Cemetery of Chatyr-Dag: Chronology of Assemblages with Roman Imports]. Saint Petersburg, Nestor-Istoriya Publ. 208 p.

Cravinho G., 2017. Roman Engraved Gems in the National Archaeological Museum in Lisbon. Studies in Ancient Art and Civilization, vol. 21, pp. 173-245.

Khrapunov I., Kazanski M., 2016. A Grave from the Hunnic Period in the Cemetery of Neizats (Central Crimea). Archäologische Korrespondenzblatt, vol. 46, pp. 363-378.

Mattingly H., Sydenham E.A., 1936. The Roman Imperial Coinage, vol. IV, Pt. I: Pertinax to Geta. London, Spink \& Son. 406 p.

Spier J., 1992. Ancient Gems and Finger Rings: Catalogue of the Collections of the J. Paul Getty Museum. Malibu (Calif.), J. Paul Getty Museum. 200 p. 


\section{Information About the Authors}

Igor N. Khrapunov, Doctor of Sciences (History), Professor, Ancient and Medieval History Department, Taurida Academy, V.I. Vernadsky Crimean Federal University, Prosp. Akademika Vernadskogo, 4, 295007 Simferopol, Russian Federation, igorkhrapunov@mail.ru, https://orcid.org/0000-0002-3961-6297

Anastasiya A. Stoyanova, Candidate of Sciences (History), Senior Researcher, Institute of Archaeology of the Crimea of the Russian Academy of Sciences, Prosp. Akademika Vernadskogo, 2, 295007 Simferopol, Russian Federation, ancient2008@mail.ru, https://orcid.org/0000-0002-8364-6135

\section{Информация об авторах}

Игорь Николаевич Храпунов, доктор исторических наук, профессор кафедры истории древнего мира и средних веков, Таврическая академия Крымского федерального университета им. В.И. Вернадского, просп. Академика Вернадского, 4, 295007 г. Симферополь, Российская Федерация, igorkhrapunov@mail.ru, https://orcid.org/0000-0002-3961-6297

Анастасия Анзоровна Стоянова, кандидат исторических наук, старший научный сотрудник, Институт археологии Крыма РАН, просп. Академика Вернадского, 2, 295007 г. Симферополь, Российская Федерация, ancient2008@mail.ru, https://orcid.org/0000-0002-8364-6135 